\title{
Production of bioactive plant secondary metabolites through in vitro technologies—status and outlook
}

\author{
Christoph Wawrosch ${ }^{1}$ (D) . Sergey B. Zotchev ${ }^{1}$
}

Received: 3 May 2021 / Revised: 14 August 2021 / Accepted: 19 August 2021 / Published online: 1 September 2021

(c) The Author(s) 2021

\begin{abstract}
Medicinal plants have been used by mankind since ancient times, and many bioactive plant secondary metabolites are applied nowadays both directly as drugs, and as raw materials for semi-synthetic modifications. However, the structural complexity often thwarts cost-efficient chemical synthesis, and the usually low content in the native plant necessitates the processing of large amounts of field-cultivated raw material. The biotechnological manufacturing of such compounds offers a number of advantages like predictable, stable, and year-round sustainable production, scalability, and easier extraction and purification. Plant cell and tissue culture represents one possible alternative to the extraction of phytochemicals from plant material. Although a broad commercialization of such processes has not yet occurred, ongoing research indicates that plant in vitro systems such as cell suspension cultures, organ cultures, and transgenic hairy roots hold a promising potential as sources for bioactive compounds. Progress in the areas of biosynthetic pathway elucidation and genetic manipulation has expanded the possibilities to utilize plant metabolic engineering and heterologous production in microorganisms. This review aims to summarize recent advances in the in vitro production of high-value plant secondary metabolites of medicinal importance.
\end{abstract}

Key points

- Bioactive plant secondary metabolites are important for current and future use in medicine

- In vitro production is a sustainable alternative to extraction from plants or costly chemical synthesis

- Current research addresses plant cell and tissue culture, metabolic engineering, and heterologous production

Keywords Plant secondary metabolites $\cdot$ Plant tissue culture $\cdot$ Cell suspension $\cdot$ Hairy roots $\cdot$ Heterologous production

\section{Introduction}

Mankind has been using medicinal plants since thousands of years (Fabricant and Farnsworth 2001; Kinghorn et al. 2011), and herbal medicines continue to be used around the world, particularly, but not solely, in developing countries (Robinson and Zhang 2011). Isolation of morphine from the opium poppy Papaver somniferum by Sertürner some 200 years ago (Klockgether-Radke 2002), and the subsequent isolation of compounds like, e.g., cocaine or digitoxine, marked the beginning of rational drug discovery (Pferschy-Wenzig and Bauer 2015), as plant-derived drugs could now be administered much more precisely compared to the crude herbal extracts ( $\mathrm{Li}$ and Vederas 2009). Isolation

Christoph Wawrosch

christoph.wawrosch@univie.ac.at

1 Department of Pharmaceutical Sciences, Division of Pharmacognosy, University of Vienna, Vienna, Austria and characterization of biologically active compounds from medicinal plants is ongoing, with the aim of either direct use of such plant secondary metabolites as drugs, or as templates for synthetic modification (Balunas and Kinghorn 2005; Atanasov et al. 2015; Chen et al. 2015). About 15,000 or ca. $5 \%$ of all estimated species of higher plants have documented medicinal use (Cordell and Colvard 2005). This knowledge, together with the potential use of yet unexplored species are of great value for the discovery of new bioactive natural products (Fabricant and Farnsworth 2001; Rates 2001; Cordell and Colvard 2005; Albuquerque et al. 2012). The plant microbiome has been recognized as a source of novel bioactive compounds, too (Atanasov et al. 2021; Oberhofer et al. 2021; Bekiesch et al. 2021).

Some of the plant secondary metabolites extensively used today in medical practice are shown in Fig. 1. In view of rising extinction rates of plant species (Brower 2008; Urban 2015) and of the importance of biodiversity conservation (Kingston 2011), issues of supply of plant material, and, 
<smiles>COc1cc2c(c(OC)c1OC)-c1ccc(OC)c(=O)cc1[C@@H](NC(C)=O)CC2</smiles>

(antigout)

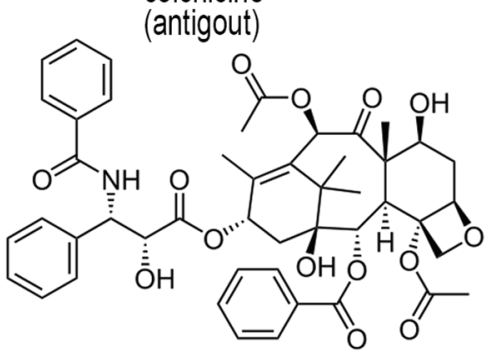

paclitaxel (anticancer)

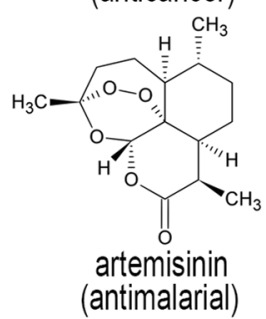<smiles>CCC1CN2CCc3cc(OC)c(OC)cc3[C@H]2C[C@H]1C[C@H]1NCCc2cc(OC)c(OC)cc21</smiles>

emetine (expectorant)

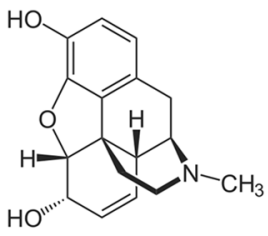

morphine (analgetic)<smiles>CNC(=O)Oc1ccc2c(c1)C1(C)CCN(C)[C@H]1N2C</smiles>

physostigmin (miotic)

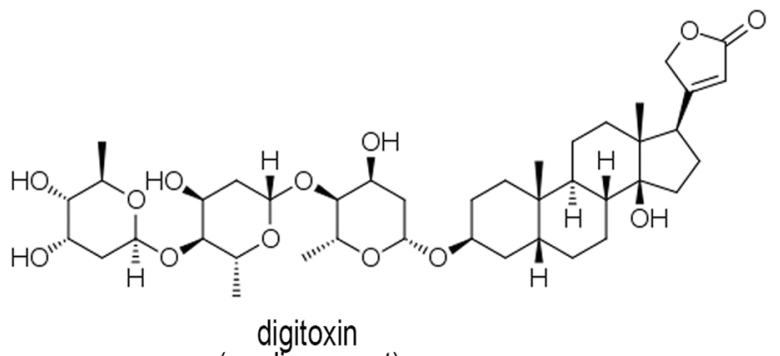
(cardiac agent)<smiles>COc1ccc2c3c1O[C@H]1CC(O)C=CC31CCN(C)C2</smiles>

galanthamine (anti-alzheimer)<smiles>CN1C2CCC1CC(OC(=O)[C@H](CO)c1ccccc1)C2</smiles>

scopolamine (antiemetic)

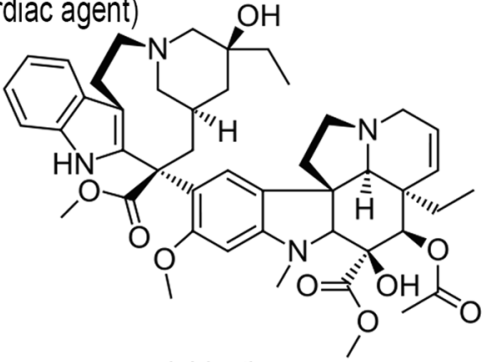

vinblastine (anticancer)<smiles>C=CCc1ccc(O)c(OC)c1</smiles>

eugenol (antiseptic)

Fig. 1 Chemical structures of some bioactive plant secondary metabolites used in medicine

consequently, plant-derived compounds, must be considered as early as possible (McChesney et al. 2007; Salim et al. 2008). Because of the frequently found structural complexity of plant secondary metabolites, very often their chemical synthesis is economically unfeasible (Staniek et al. 2014; Dziggel et al. 2017). In most cases, only low to minimal amounts of the natural products of interest occur in the respective species, and due to various plant-specific and environmental factors the content in wild-growing plants can be highly variable (Canter et al. 2005; Pferschy-Wenzig and Bauer 2015; Ochoa-Villarreal et al. 2016). Therefore, alternatives to harvesting the plant material from natural resources are highly desired. The application of plant tissue culture techniques offers a range of opportunities for a sustainable access to natural products.

A number of recent reviews deals with plant tissue culture for the production of secondary compounds, for example by Chandran et al. (2020), Gutierrez-Valdes et al. (2020), Marchev et al. (2020), Cardoso et al. (2019), Kreis (2019), Rahmat and Kang (2019), and more. The present minireview on the one hand highlights recent achievements in the production of medically important plant secondary metabolites using various in vitro technologies, including most recent approaches like metabolic engineering and heterologous production in microorganisms. In addition, progress in the optimization of in vitro productivity will be analyzed on the basis of selected compounds.

\section{Production via plant in vitro cultures}

The methodology for initiating the in vitro cultures of plant cells, tissues, and organs is nowadays well established, and a brief overview of the most important procedures is illustrated in Fig. 2. The cultures can be initiated from parts of the whole plant, or from seeds which are germinated aseptically. A prerequisite for introducing any plant material into in vitro culture is the surface sterilization in order to eliminate adhering microorganisms, this is usually performed with aqueous solutions of disinfectants like, e.g., sodium hypochlorite. Suitable explants are then inoculated on a semi-solid medium containing adequate amounts of nutrients and, most importantly, plant growth regulators, and cultivated under controlled environmental conditions. Depending 


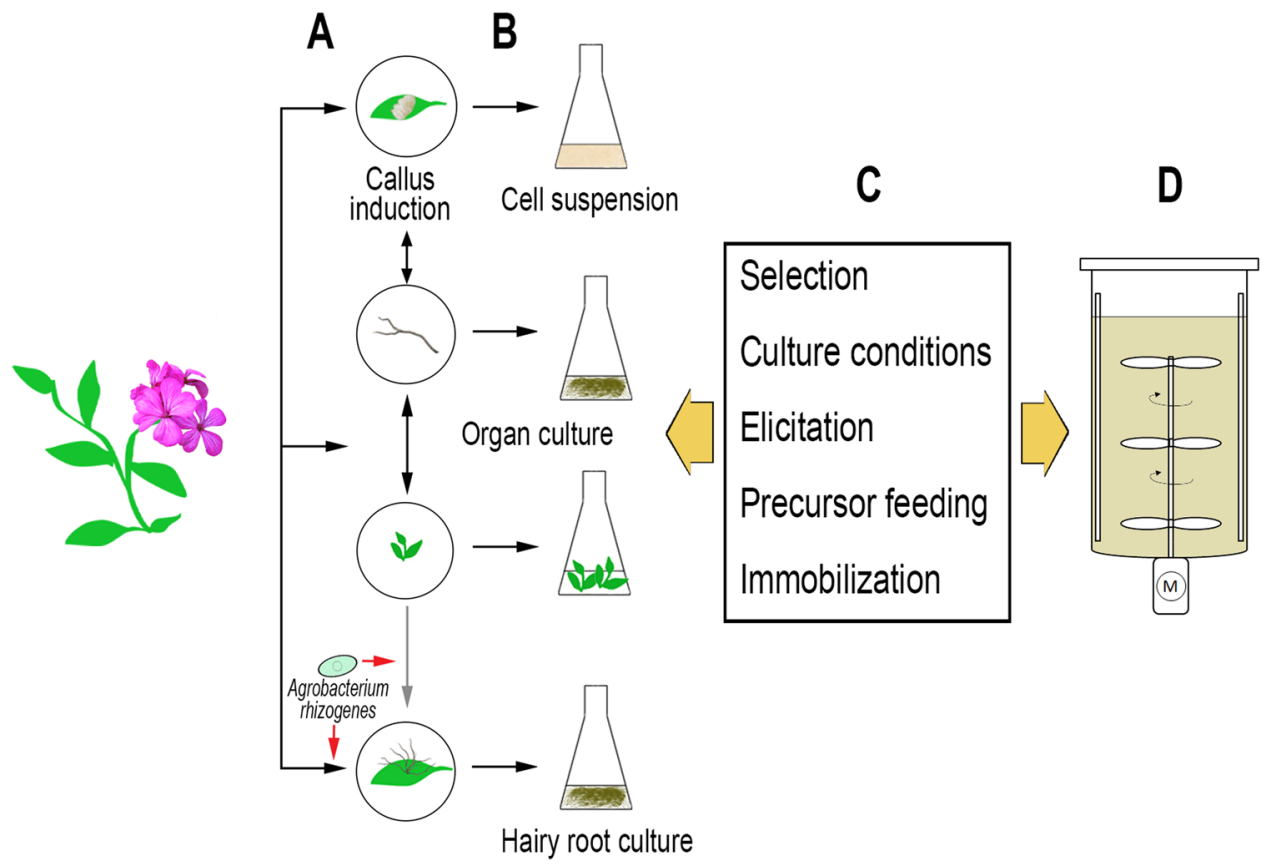

Fig. 2 Methods for the production of bioactive secondary metabolites through plant in vitro culture. A Establishment of in vitro cultures after surface sterilization of plant material. Callus formation can also be induced on material from organ cultures. Reversely, organs like roots or shoots can be regenerated from callus. Hairy roots are obtained by infection of sterilized donor plant, or in vitro cultivated material, with Agrobacterium rhizogenes. B Multiplication of primary callus/organs/roots, first selection, and establishment of liq-

on the starting material and the nutrient medium, different types of cultures can be established which are classified as cell cultures (cell suspensions, protoplasts, or gametic cells), tissue cultures (callus or differentiated tissues), or organ cultures (e.g., shoots, roots, or zygotic embryos). On the one hand, the formation of callus (dedifferentiated cell masses) can be induced, and upon transfer to liquid medium clumps of callus might disintegrate into small aggregates and single cells, whereby cell suspension cultures are obtained. As callus typically is quite heterogeneous with respect to the biochemical properties of the cells, suspension cultures should be started from small callus aggregates, so that homogeneous cell lines, desirably with a fast growth, can evolve. Cell suspension cultures are a potential source for the production of high-value plant secondary metabolites, and during the past decades cultures from many medicinal plants have been established (see, e.g., Karuppusamy 2009). On the other hand, shoot tips or axillary buds of a donor plant will grow to shoot cultures on an appropriate nutrient medium. When such shoots are regularly dissected and bud-bearing segments subcultivated, it is possible to achieve high multiplication rates, and the micropropagation especially of ornamental plants is nowadays applied widely on a commercial basis (Preil 2003). For the purpose of secondary metabolite uid cultures. C Selection of high yielding lines and optimization of culture conditions (nutrient medium composition, inoculum density, temperature, light, agitation and aeration). Strategies like elicitation, precursor feeding, or immobilization are pursued to further improve productivity. D The bioreactor design will depend on the culture type: stirred tanks, but also airlift and bubble column reactors for cell suspensions; mist or spray reactors and temporary immersion systems for organ cultures (including hairy roots)

production, most often research focuses on cell suspension cultures because of comparatively fast growth and the possibility of scale-up to bioreactor systems. However, it must be considered that in higher plants some biochemical traits may only be fully developed in specific organs, or during particular stages of development. Thus, the accumulation of such metabolites may depend on the presence of certain cell types or organelles, and the expression and regulation of biosynthetic genes (Kreis 2007). For this reason, past and ongoing studies also deal with the application of in vitro cultured organs like shoots, roots, or embryos for the production of plant metabolites, although the high costs of largescale cultivation because of the need for special bioreactors have hitherto largely impeded a commercial implementation (Verpoorte et al. 2002).

Hairy roots cultures are of particular interest for the production of compounds which are biosynthesized in roots. The hairy roots disease is caused by the soil-borne Agrobacterium rhizogenes which upon infection transfers genes into the host plant, some of which encode for growth hormone biosynthesis. This procedure can be carried out in the lab, and the resulting hairy root cultures feature rapid growth in simple media, genetic stability, and the capacity of secondary metabolite production in equal or higher 
amounts than the host plant (Kumar 2015). In addition, by manipulating the bacterial Ri plasmid genes of interest can be introduced into hairy roots. Over the past few decades, hairy roots have gained increased interest as a biotechnological tool not only for the production of plant secondary metabolites, but also for the elucidation of biosynthetic pathways, studies of rhizosphere physiology and biochemistry, metabolic engineering, and phytoremediation (Talano et al. 2012; Gutierrez-Valdes et al. 2020). In vitro they exhibit fast growth, are genetically stable, and can accumulate the same secondary metabolites as the parent plant. Hairy roots of over 100 medicinal plants have been investigated so far (see for example (Dhiman et al. 2018), and a few of the most recent studies are reviewed below.

Most often, in a given plant in vitro culture the content of a desired secondary metabolite can initially be quite low, particularly in callus and cell suspension cultures. Hence, when cell cultures are to be developed, screening for high yielding and fast-growing lines should be undertaken-this also applies to hairy roots because an infection experiment with $A$. rhizogenes usually results in the emergence of several distinct hairy root lines which may vary in properties like growth and secondary metabolite accumulation. Next, for any type of in vitro cultures the optimization of the culture conditions with respect to factors such as nitrogen source, carbon source, plant growth regulators, medium $\mathrm{pH}$, temperature, light and oxygen is likely to improve product formation. Elicitation is an important and expedient strategy to enhance the productivity of the culture. Elicitors are compounds that stimulate various mechanisms of plant defense and thus promote the biosynthesis of secondary metabolites to protect the cell and the whole plant (Ramirez-Estrada et al. 2016). Biotic elicitors are substances of biological origin, like polysaccharides originated from plant cell walls and micro-organisms, fungal and bacterial lysates, or yeast extract. Abiotic elicitors are of non-biological origin and include physical (osmotic stress, UV light, ultrasound, etc.), chemical (e.g., heavy metals or mineral salts) and hormonal factors like salicylic acid or jasmonates.

The in vitro production of secondary metabolites has a number of distinct advantages over the extraction from whole plants. There are no seasonal constraints and a predictable, reliable, and continuous year-round production is possible. It is of special interest when a plant species is slow growing or difficult to cultivate at all, and when the content of the desired compound in planta is exceedingly low. In some cases, it has been shown that upon optimization product accumulation in vitro can exceed the content in whole plants. However, in view of the fact that many authors claim that their in vitro system will allow for the commercial production of the respective compound, a few economic considerations are necessary. As recently discussed by Lange (2018), a number of factors are likely to affect how a given target compound is obtained on an industrial scale. Although many natural compounds have a very complex chemical structure, just as many exhibit a comparatively uncomplicated structure. In the latter case, chemical synthesis of the compound will be economically superior to a plant-based production (both through extraction from plant raw materials, or through plant in vitro culture). Concerning the isolation of compounds from plant material, criteria like price of the raw material, concentration of the desired natural product, and costs of the extraction/purification process are further factors to consider, as are market size and regulatory provisions.

Recent achievements in the production of bioactive secondary metabolites in cell suspension cultures, as well as organ cultures (including hairy roots), are reviewed in the following sections and summarized in Table 1.

\section{Alkaloids}

Among the large variety of secondary metabolites synthesized by plants, alkaloids exhibiting various pronounced biological activities are being extensively used in medicine. Most prominent examples are atropine and scopolamine, quinine, ephedrine, or the opium poppy alkaloids codeine and morphine, only to name a few. Despite the importance of this class of compounds, only limited studies on their in vitro production have been reported. Berberine is a benzylisoquinoline alkaloid found in many plant genera like, e.g., Berberis, Argemone, Eschscholzia, or Coptis (Neag et al. 2018), and exhibiting effects on the cardiovascular, gastrointestinal, endocrine, immune, and central nervous systems (Imanshahidi and Hosseinzadeh 2008). In a recent study on berberine formation in the in vitro cultures of prickly poppy (Argemone mexicana L., Papaveraceae) the authors demonstrated that alkaloid biosynthesis is related to the level of tissue organization (Monforte-González et al. 2019). Berberine was found in leaves and stems used as initial explants, and in shoots and roots regenerated from callus $\left(1.3 \mathrm{mg} \cdot \mathrm{g}^{-1} \mathrm{DW}\right.$ and ca. $0.8 \mathrm{mg} \cdot \mathrm{g}^{-1} \mathrm{DW}$, respectively). Research in the field of the in vitro production of berberine is carried out since some decades. Notably, selected cell lines of Coptis japonica with a production of up to $13.2 \%$ (DW) have been reported by Sato and Yamada (1984).

The monoterpenoid pentacyclic alkaloid camptothecin is a cytotoxic compound originally isolated from the Chinese tree Camptotheca acuminata (Liu et al. 2015) but also found in other plant species. While camptothecin itself is not used as a drug, it serves as starting material for the semisynthetic preparation of important antitumor drugs like, e.g., topotecan and irinotecan (Kacprzak 2013). Deepthi and Satheeshkumar (2017b) have investigated camptothecin formation in suspension cultures of Ophiorrhiza mungos. 
Table 1 Bioactive secondary metabolites obtained via plant in vitro cultures

\begin{tabular}{|c|c|c|c|c|}
\hline Compound & Plant species & Product yield & Culture type & Reference \\
\hline \multicolumn{5}{|l|}{ Alkaloids } \\
\hline Berberine & Argemone mexicana & ca. $1.3 \mathrm{mg}^{-1} \mathrm{DW}$ & SH & Monforte-González et al. (2019) \\
\hline Camptothecin & Ophiorrhiza mungos & $\begin{array}{l}0.86 \mathrm{mg} \cdot \mathrm{g}^{-1} \mathrm{DW} \\
1.12 \mathrm{mg} \cdot \mathrm{g}^{-1} \mathrm{DW}\end{array}$ & $\begin{array}{l}\text { AR } \\
S\end{array}$ & $\begin{array}{l}\text { Deepthi and Satheeshkumar } \\
\text { (2017a); } \\
\text { Deepthi and Satheeshkumar } \\
\text { (2017b) }\end{array}$ \\
\hline Capsaicin \& dihydrocapsaicin & Capsicum chinense & $2.87 / 1.03 \mathrm{mg} \cdot \mathrm{g}^{-1} \mathrm{DW}$ & $\mathrm{S}$ & Kabita et al. (2020) \\
\hline Indole alkaloids & Isatis tinctoria & $3.15 \mathrm{mg} \cdot \mathrm{g}^{-1} \mathrm{DW}$ & HR & Gai et al. (2019) \\
\hline \multicolumn{5}{|l|}{ Phenylpropanoids } \\
\hline Chlorogenic acid derivatives & Gardenia jasminoides & $20.98 \mathrm{mg} \cdot \mathrm{g}^{-1} \mathrm{DW}$ & $\mathrm{S}$ & Liu et al. (2018) \\
\hline Cichoric acid & Ocimum basilicum & $6.90 \mathrm{mg} \cdot \mathrm{g}^{-1} \mathrm{DW}$ & $\mathrm{S}$ & Açıkgöz (2020) \\
\hline \multicolumn{5}{|l|}{ Flavonoids (total) } \\
\hline & Ficus deltoidea var. kunstleri & $3.3 \mathrm{mg}^{-1} \mathrm{DW}$ & $\mathrm{S}$ & Haida et al. (2019) \\
\hline $\begin{array}{l}\text { Flavonoids (chrysin, wogonin } \\
\text { and baicalein) }\end{array}$ & Scutellaria bornmuelleri & $163.42 \mathrm{mg}^{-1} \mathrm{DW}$ & HR & Gharari et al. (2020a) \\
\hline $\begin{array}{l}\text { Flavonoids, phenolics, polysac- } \\
\text { charides }\end{array}$ & Oplopanax elatus & $\begin{array}{l}53.87 / 30.10 / 192.64 \mathrm{mg}^{-1}{ }^{-1} \\
\text { DW }\end{array}$ & AR & Jiang et al. (2017) \\
\hline Isoflavones & Trifolium pratense & $23.53 \mathrm{mg} \cdot \mathrm{g}^{-1} \mathrm{DW}$ & IVP & Reis et al. (2018) \\
\hline Isoquercetin & Ocimum basilicum & $3.72 \mathrm{mg}^{-1} \mathrm{DW}$ & $\mathrm{S}$ & Açıkgöz (2020) \\
\hline \multirow[t]{2}{*}{ Rosmarinic acid } & Ocimum basilicum & $22.53 \mathrm{mg} \cdot \mathrm{g}^{-1} \mathrm{DW}$ & $\mathrm{S}$ & Açıkgöz (2020) \\
\hline & Salvia leriifolia & $6.41 \mathrm{mg} \cdot \mathrm{g}^{-1} \mathrm{DW}$ & $\mathrm{S}$ & Modarres et al. (2018) \\
\hline Rutin & Ocimum basilicum & $6.54 \mathrm{mg} \cdot \mathrm{g}^{-1} \mathrm{DW}$ & $\mathrm{S}$ & Açıkgöz (2020) \\
\hline \multicolumn{5}{|l|}{ Lignans } \\
\hline Lignans (total) & Linum album & $122.73 \mu \cdot \mathrm{g}^{-1} \mathrm{FW}$ & HR & Ahmadian Chashmi et al. (2016) \\
\hline $\begin{array}{l}\text { Dehydrodiconiferyl alcohol } \\
\text { glucoside }\end{array}$ & Linum usitatissimum & $21.6 \mathrm{mg} \cdot \mathrm{g}^{-1} \mathrm{DW}$ & AR & Anjum et al. (2020) \\
\hline $\begin{array}{l}\text { Guaiacylglycerol-ß-coniferyl } \\
\text { alcohol ether glucoside }\end{array}$ & Linum usitatissimum & $4.9 \mathrm{mgg}^{-1} \mathrm{DW}$ & $\mathrm{AR}$ & Anjum et al. (2020) \\
\hline Lariciresinol diglucoside & Linum usitatissimum & $11.9 \mathrm{mg}^{-1} \mathrm{DW}$ & $\mathrm{AR}$ & Anjum et al. (2020) \\
\hline $\begin{array}{l}\text { Podophyllotoxin / 6-methoxy- } \\
\text { podo-phyllotoxin }\end{array}$ & Linum album & $\begin{array}{l}47 / 9.5 \mu \mathrm{g} \cdot \mathrm{g}^{-1} \mathrm{DW} \\
135 \mu \mathrm{g} \cdot \mathrm{g}^{-1} \mathrm{DW} / 15 \mathrm{mg}^{-1} \\
\text { DW } \\
\text { ca. } 60 \mu \mathrm{g} \cdot \mathrm{g}^{-1} \mathrm{DW} / 9.5 \mathrm{mg} \cdot \mathrm{g}^{-1} \\
\text { DW }\end{array}$ & $\begin{array}{l}\mathrm{S} \\
\mathrm{AR} \\
\mathrm{HR}\end{array}$ & $\begin{array}{l}\text { Lalaleo et al. (2018) } \\
\text { Lalaleo et al. (2018) } \\
\text { Lalaleo et al. (2018) }\end{array}$ \\
\hline $\begin{array}{l}\text { Secoisolariciresinol digluco- } \\
\text { side }\end{array}$ & Linum usitatissimum & $5.5 \mathrm{mg} \cdot \mathrm{g}^{-1} \mathrm{DW}$ & $\mathrm{AR}$ & Anjum et al. (2020) \\
\hline \multicolumn{5}{|l|}{ Stilbenes } \\
\hline $\begin{array}{l}\text { Mulberroside A } \\
\text { Terpenoids }\end{array}$ & Morus alba & $31.59 \mathrm{mg} \cdot \mathrm{L}^{-1}$ & $\mathrm{~S}$ & Komaikul et al. (2019) \\
\hline \multicolumn{5}{|l|}{ Terpenoids } \\
\hline \multirow[t]{2}{*}{ Artemisinin } & Artemisia аппиа & $\begin{array}{l}10.86 \mathrm{mg} \cdot \mathrm{g}^{-1} \mathrm{DW} \\
9.33 \mathrm{mg} \mathrm{L}^{-1}\end{array}$ & $\begin{array}{l}\mathrm{S} \\
\mathrm{S}\end{array}$ & $\begin{array}{l}\text { Zebarjadi et al. (2018) } \\
\text { Salehi et al. (2019a) }\end{array}$ \\
\hline & & $1.12 \mathrm{mg}^{-1} \mathrm{gW}$ & HR & Patra and Srivastava (2016) \\
\hline Betulinic acid & Lantana camara & $0.117 \mathrm{mg} \cdot \mathrm{g}^{-1} \mathrm{DW}$ & $\mathrm{S}$ & Kumar et al. (2016) \\
\hline Bilobalide & Ginkgo biloba & $78 \mathrm{mg} \cdot \mathrm{g}^{-1} \mathrm{DW}$ & $\mathrm{S}$ & Sukito and Tachibana (2016) \\
\hline Ginkgolide A / B / C & Ginkgo biloba & $79 / 71 / 7.5 \mathrm{mg}^{-1} \mathrm{DW}$ & $\mathrm{S}$ & Sukito and Tachibana (2016) \\
\hline \multirow[t]{3}{*}{ Ginsenosides } & Panax ginseng & $\begin{array}{l}2.62-9.04{\mathrm{mg} \cdot \mathrm{g}^{-1} \mathrm{DW}} \\
32.46 \mathrm{mg} \cdot \mathrm{g}^{-1} \mathrm{DW}\end{array}$ & $\begin{array}{l}\mathrm{S} \\
\mathrm{AR}\end{array}$ & $\begin{array}{l}\text { Le et al. (2019) } \\
\text { Murthy et al. (2018) }\end{array}$ \\
\hline & Panax quinquefolius & $87.6 \mathrm{mg} \cdot \mathrm{L}^{-1}$ & $\mathrm{~S}$ & Biswas et al. (2016) \\
\hline & Panax sikkimensis & $222.2 \mathrm{mg} \cdot \mathrm{L}^{-1}$ & $\mathrm{~S}$ & Biswas et al. (2018) \\
\hline \multirow[t]{2}{*}{ Oleanolic acid } & Lantana camara & $1.43 \mathrm{mg}^{-1} \mathrm{DW}$ & $\mathrm{S}$ & Kumar et al. (2016) \\
\hline & Salvia fruticosa & $5.76 \mathrm{mg} \cdot \mathrm{g}^{-1} \mathrm{DW}$ & $\mathrm{S}$ & Kümmritz et al. (2016) \\
\hline Oleanolic acid glycosides & Calendula officinalis & $52.52 \mathrm{mg} \cdot \mathrm{g}^{-1} \mathrm{DW}$ & HR & Alsoufi et al. (2019) \\
\hline
\end{tabular}


Table 1 (continued)

\begin{tabular}{|c|c|c|c|c|}
\hline Compound & Plant species & Product yield & Culture type & Reference \\
\hline \multirow[t]{2}{*}{ Paclitaxel } & Corylus avellana & $\begin{array}{l}404.5 \mu \mathrm{g} \cdot \mathrm{L}^{-1} \\
402.4 \mu \mathrm{g} \cdot \mathrm{L}^{-1} \\
3.2 \mu \mathrm{g} \cdot \mathrm{g}^{-1} \mathrm{DW}\end{array}$ & $\begin{array}{l}S \\
S \\
\text { HR }\end{array}$ & $\begin{array}{l}\text { Salehi et al. (2019b) } \\
\text { Farhadi et al. (2020) } \\
\text { Jalalipour Parizi et al. (2020) }\end{array}$ \\
\hline & Taxus $x$ media & $2.47 \mathrm{mg} \cdot \mathrm{g}^{-1} \mathrm{DW}$ & HR & Sykłowska-Baranek et al. (2019) \\
\hline $\begin{array}{l}\text { Steviol glycosides (stevio- } \\
\text { side + rebaudioside A) }\end{array}$ & Stevia rebaudiana & $92.58 \mathrm{mg}^{-1} \mathrm{~g}^{-1} \mathrm{DW}$ & $\mathrm{AR}$ & Ahmad et al. (2018) \\
\hline \multirow[t]{2}{*}{ Ursolic acid } & Lantana camara & $3.87 \mathrm{mg}^{-1} \mathrm{DW}$ & $\mathrm{S}$ & Kumar et al. (2016) \\
\hline & Salvia fruticosa & $10.77 \mathrm{mg}^{-1} \mathrm{~g}^{-1} \mathrm{DW}$ & $\mathrm{S}$ & Kümmritz et al. (2016) \\
\hline Withanolides & Withania somnifera & $14.2 \mathrm{mg} \cdot \mathrm{g}^{-1} \mathrm{DW}$ & $\mathrm{S}$ & Ahlawat et al. (2017) \\
\hline \multicolumn{5}{|l|}{ Other } \\
\hline L-Dopa & Hybanthus enneaspermus & $12.64 \mathrm{mg}^{-1} \mathrm{DW}$ & $\mathrm{AR}$ & Sathish et al. (2020) \\
\hline
\end{tabular}

$A R$ adventitious root culture, $D W$ dry weight, $H R$ hairy roots, $I V P$ in vitro cultivated plant, $S$ cell suspension culture, $S H$ shoot culture

Through cell line selection, optimization of the nutrient medium, and elicitation with jasmonic acid, the authors achieved a camptothecin production of $1.12 \mathrm{mg} \cdot \mathrm{g}^{-1} \mathrm{DW}$ (dry weight) compared to $0.06 \mathrm{mg} \cdot \mathrm{g}^{-1} \mathrm{DW}$ in the original cell line. The accumulation of camptothecin in adventitious roots of Ophiorrhiza mungos has been studied by Deepthi and Satheeshkumar (2017a), who showed that camptothecin production was influenced by the nutrient medium (concentration of major nutrients, plant growth regulators) and by inoculum size. Under optimized conditions the in vitro cultures produced $0.86 \mathrm{mg} \cdot \mathrm{g}^{-1} \mathrm{DW}$ of the alkaloid, which was well above the concentration of $0.15 \mathrm{mg} \cdot \mathrm{g}^{-1} \mathrm{DW}$ found in the roots of the donor plant used for culture establishment. Studies on the in vitro production of camptothecin started more than 40 years ago (for a review see Kai et al. 2015). In cell suspension cultures of $C$. acuminata treated with a protein elicitor from the fungus Phytophthora boehmeriae, $\mathrm{Lu}$ et al. (2011) achieved the formation of $12 \mathrm{mg} \cdot \mathrm{g}^{-1} \mathrm{DW}$ camptothecin. Viewed in this light, the recent findings on camptothecin in vitro production cannot be regarded as a progress towards a possible large-scale production of the compound through plant tissue culture.

The root of Isatis tinctoria (synonym I. indigotica) has been used since centuries in Traditional Chinese Medicine for the treatment of influenza and hepatitis. It has also shown significant activity in the treatment of SARS (Xiao et al. 2015). The numerous secondary metabolites identified in the plant include various alkaloids and flavonoids (Hamburger 2002). In a hairy root line of I. tinctoria Gai et al. (2019) recently obtained $3.15 \mathrm{mg} . \mathrm{g}^{-1}$ DW alkaloids (epigoitrin, isatin, indole-3-carboxaldehyde, tryptanthrin, indigo, and indirubin) after elicitation with $142.61 \mu \mathrm{M}$ salicylic acid.

Capsaicin and several related compounds are the pungent principles of chili peppers (species from the genus Capsicum). Beside the use of chili as a spice, capsaicin has analgesic properties and possesses beneficial effects in the treatment of a number of diseases (Fattori et al. 2016). A recent study by Kabita and co-authors (Kabita et al. 2020) deals with capsaicinoid biosynthesis in cell suspension cultures of Capsicum chinense Jacq. cv. 'Umorok'. Elicitation of the cells with chitosan resulted in levels of $2.87 \mathrm{mg} \mathrm{g}^{-1}$ FW (fresh weight) capsaicin and $1.03 \mathrm{mg}^{-1} \mathrm{FW}$ dihydrocapsaicin. Although biotechnological research on in vitro production of capsaicin is now going on since decades (see, e.g., review by Kehie et al. 2015), this metabolite cannot be regarded as a target compound for the in vitro production. Depending on cultivar and processing of the fruits, capsaicin contents from 0.5 to more than $4 \%$ DW have been reported (Yaldiz et al. 2010), hence it seems a debatable point whether biotechnological capsaicin production can compete with the extraction from chili peppers.

\section{Flavonoids and phenolic acids}

Flavonoids represent another large group of natural products which are found in all higher plants. These phenolic compounds exhibit a multitude of biological activities and are used in nutrition as well as for pharmaceutical applications (Sticher 2007a; Panche et al. 2016). Many plants also produce phenolic acids with various activities like, e.g., antiinflammatory, anti-oxidative, and antiviral (Sticher 2007a). In this section, recent studies on the formation of flavonoids and phenolic acids in plant tissue cultures are presented, followed by some critical comments.

Haida et al. (2019) investigated the effects of initial inoculum size, cell aggregation and $\mathrm{pH}$ of the nutrient medium on the total flavonoid content in a cell suspension culture of Ficus deltoidea var. kunstleri. The authors reported the highest content of $3.3 \mathrm{mg} \cdot \mathrm{g}^{-1} \mathrm{DW}$ in cell suspension fractions with aggregates sized 500-750 $\mu \mathrm{m}$ and thus confirmed that although fine cell suspensions are usually preferred, aggregation can sometimes improve product formation (Mustafa et al. 2011). Chlorogenic 
acid derivatives are widely distributed phenolic plant compounds with antioxidant, anti-inflammatory, antiallergic and hydrocholeretic properties (Sticher 2007a; Upadhyay and Rao 2013). Liu et al. (2018) studied the effects of elicitation with salicylic acid and methyl jasmonate on the formation of six chlorogenic acid derivatives in suspension cultures of Gardenia jasminoides. Treatment with $200 \mu \mathrm{M}$ methyl jasmonate resulted in the accumulation of nearly $21 \mathrm{mg} \cdot \mathrm{g}^{-1}$ DW of the compounds, which was about twofold the yield of the control. Sweet basil (Ocimum basilicum L.) is a well-known herb widely used for culinary purposes and also as a herbal remedy for treating headaches, coughs, digestive, and nervous disorders (Majdi et al. 2020). The formation of flavonoids and phenolic acids in $O$. basilicum cell suspension cultures as influenced by elicitors $\left(\mathrm{AgNO}_{3}, \mathrm{CdCl}_{2}\right.$, and yeast extract) was studied by Aç1kgöz (2020). Depending on the treatment, the author reported an enhanced flavonoid formation of up to $6.54 \mathrm{mg} \cdot \mathrm{g}^{-1}$ DW rutin and $3.72 \mathrm{mg} \cdot \mathrm{g}^{-1}$ DW isoquercetin. The accumulation of rosmarinic acid $\left(22.53 \mathrm{mg}^{-1}\right.$ DW) and cichoric acid $\left(6.90 \mathrm{mg} \cdot \mathrm{g}^{-1} \mathrm{DW}\right)$ was stimulated through elicitor treatment, too. However, no figures are given of the content of these compounds in planta. This hampers a comparative evaluation of the results, especially because of the multitude of basil varieties and cultivars which can vary considerably in their content of bioactive compounds (Makri and Kintzios 2008; Srivastava et al. 2014). Modarres et al. (2018) reported the formation of $6.41 \mathrm{mg} \cdot \mathrm{g}^{-1} \mathrm{DW}$ rosmarinic acid in cell suspension cultures of Salvia leriifolia. Elicitation of a Isatis tinctoria hairy root line ("ITHRL V") with $179.54 \mu \mathrm{M}$ methyl jasmonate resulted in the accumulation of $4.96 \mathrm{mg}^{-1} \mathrm{DW}$ flavonoids (rutin, neohesperidin, buddleoside, liquiritigenin, quercetin, isorhamnetin, kaempferol, and isoliquiritigenin)(Gai et al. 2019). The formation of isoflavones in the in vitro cultivated whole plants of Trifolium pratense was investigated by Reis et al. (2018). After a cultivation period of 60 days in vitro plants showed a higher total isoflavone content $\left(23.55 \mathrm{mg} \cdot \mathrm{g}^{-1} \mathrm{DW}\right)$ than the two analysed wild plants (14.52 and $16.51 \mathrm{mg} \cdot \mathrm{g}^{-1} \mathrm{DW}$, respectively). Interestingly, only a low amount of the compound daidzein, which was found in the in vitro plants at a level of $17.59 \mathrm{mg} \cdot \mathrm{g}^{-1} \mathrm{DW}$, could be detected in one of the wild plant samples $\left(0.37 \mathrm{mg}^{-1} \mathrm{DW}\right)$. The authors concluded that in vitro plants could be a source for the commercial production of red clover isoflavones. However, a comparison of the in vitro isoflavone content to only two wild plant samples cannot be regarded as statistically meaningful. Also, it has been reported earlier that the isoflavone content in different plant parts of $T$. pratense varied according to the vegetation period (Gikas et al. 2008). Last but not least, red clover is one of the most important forage plants which is cultivated worldwide (Boller et al. 2010), and the isoflavone content can be as high as $2.5 \% \mathrm{DW}$ (Saloniemi et al. 1995). Hence, it seems unprobable that in vitro production of these isoflavones could compete to extraction from plant material.

The roots of Oplopanax elatus, a member of the Araliaceae family, are used medicinally in China, Korea, and Russia for the treatment of various disorders like, e.g., chronic fatigue syndrome, cardiovascular diseases, diabetes mellitus and rheumatism. Among various compounds such as essential oils, saponins, or anthraquinones, the roots also contain $0.9 \%$ flavonoids (Shikov et al. 2014). The formation of flavonoids, phenolics and polysaccharides in adventitious root cultures of $O$. elatus was investigated by Jiang et al. (2017). Upon elicitation with $200 \mu \mathrm{M}$ methyl jasmonate they observed the accumulation of $53.87 \mathrm{mg} \mathrm{g}^{-1}$ DW flavonoids and $192.64 \mathrm{mg}^{-1}$ DW polysaccharides, while treatment with $100 \mu \mathrm{M}$ salicylic acid led to the production of $30.10 \mathrm{mg}^{-1} \mathrm{~g}^{-1} \mathrm{DW}$ phenolics. The authors expect this adventitious root system to be used commercially, but it is not known whether only the three compound classes measured in this study are responsible for the biological activities. Hence, while a flavonoid content of $5 \%$ as determined in the adventitious roots is undoubtedly high, further studies are necessary. Species of the genus Scutellaria (Lamiaceae) are widely used medicinally in East Asia due to is anti-inflammatory, antithrombotic, sedative, antiviral, and antioxidant effects (Shang et al. 2010). A recent paper deals with the effects of different elicitors (methyl jasmonate, methyl- $\beta$-cyclodextrin, and chitosan) on the production of the three main flavonoids chrysin, wogonin, and baicalein in hairy roots of Scutellaria bornmuelleri (Gharari et al. 2020a). The best results were obtained upon treatment with $50 \mathrm{mg} \mathrm{L}^{-1}$ chitosan together with $100 \mu \mathrm{M}$ methyl jasmonate, which yielded a total of $163.42 \mathrm{mg} \mathrm{g}^{-1}$ DW flavonoids $\left(56.47 \mathrm{mg} \cdot \mathrm{g}^{-1} \mathrm{DW}\right.$ chrysin $+27.26 \mathrm{mg} \cdot \mathrm{g}^{-1}$ DW wogonin $+79.69 \mathrm{mg}^{-1}$ DW baicalein). Hence, the flavonoid yield of this hairy roots system was clearly superior to intact roots which were shown to contain a total of only $0.0328 \mathrm{mgg}^{-1}$ DW flavonoids (Gharari et al. 2020b).

While apparently much current research is focused on the production of flavonoids through plant tissue culture, it is questionable whether these secondary metabolites are suitable target compounds. Firstly, flavonoids are found in often considerable concentrations in a large number of plants (see, e.g., Panche et al. 2016). Indeed, some compounds are extracted commercially from plant raw materials, like, e.g., hesperidin from citrus peel (Cheigh et al. 2012), or rutin from buckwheat or Eucalyptus sp. (e.g., Shafi and Ikram 1982). Herein, the development of improved extraction processes (Chávez-González et al. 2020) will further improve the economic efficiency of flavonoid production from plant materials. Also, considerable progress has been achieved in the heterologous production of flavonoids in microbial hosts 
(see for example Trantas et al. 2015), and some examples will be presented below.

Similarly, quite a number of studies deal with the production of rosmarinic acid and other phenolic acids. Research into the in vitro formation of rosmarinic acid has begun many decades ago. As reviewed by Pezeshki and Petersen (2018), the first respective studies with callus and cell suspension cultures of Coleus blumei were published in 1977, and in 1985 a bioreactor process with a yield of $21 \% \mathrm{DW}$ or $5.5 \mathrm{~g} \mathrm{~L}^{-1}$ was described (Ulbrich et al. 1985). Other production processes with various plant genera have since been developed, like, e.g., cell suspension cultures of Salvia officinalis with a productivity of $6.4 \mathrm{~g} \cdot \mathrm{L}^{-1}$ rosmarinic acid (Hippolyte et al. 1992). It has been considered that none of these highly productive systems have been commercialized because of medicinal applications of the pure substance have not been developed (Pezeshki and Petersen 2018). Nevertheless, although recently reported in vitro systems quoted above cannot compete with the early processes based on Coleus or Salvia, the authors still claim that their findings could have commercial potential.

\section{Stilbenes}

Mulberroside A (the diglucoside of oxyresveratrol) is a stilbene representing one of the main bioactive compounds in mulberry (Morus alba L.). Numerous potential health benefits are attributed to this group of natural products known as phytostilbenes (Reinisalo et al. 2015). Komaikul et al. (2019) investigated phytostilbene formation in cell suspension cultures of mulberry cultivated in different bioreactors. A level of $31.59 \mathrm{mg} \mathrm{L}^{-1}$ mulberroside $\mathrm{A}$ was achieved, and the authors demonstrated that the production was influenced by factors like aeration, biomass circulation in the bioreactor, and endogenous enzymatic hydrolysis (which can occur upon cell disruption). Mulberry contains up to $1.3 \%$ mulberroside A (Jiang et al. 2018) and the plant is fast-growing and widely distributed in the Northern and Southern hemispheres (Wen et al. 2019). Hence, it is questionable whether a biotechnological production of mulberroside A can be economically competitive to the extraction from raw plant material.

\section{Lignans}

Among the various phenylpropanoids which occur in the plant kingdom, lignans are structurally diverse compounds which exhibit potent biological activities (Barker 2019). The clinically important anticancer drugs etoposide, etopophos and teniposide have been developed from podophyllotoxin, a lignan found in species of the genus Podophyllum (Canel et al. 2000). The species Linum album contains the lignans podophyttotoxin (PTOX) and 6-methoxypodophyllotoxin (6-MPTOX) (Schmidt et al. 2010). Lalaleo et al. (2018) investigated lignan formation in different types of $L$. album in vitro culture. They reported the accumulation of $47 \mu \mathrm{g} \cdot \mathrm{g}^{-1}$ DW PTOX and $9.5 \mu \mathrm{gg}^{-1}$ DW 6-MPTOX in cell suspension cultures, while adventitious root cultures were shown to accumulate the lignans podophyllotoxin and 6-methoxypodophyllotoxin at levels of $135 \mu^{-1} \mathrm{~g}^{-1} \mathrm{DW}$ and $15 \mathrm{mg} \cdot \mathrm{g}^{-1}$ DW, respectively. Anjum et al. (2020) studied the formation of lignans and neolignans in adventitious root cultures of flax. They could detect lignans at levels of $11.9 \mathrm{mg}^{-1} \mathrm{~g}^{-1} \mathrm{DW}$ (lariciresinol diglucoside) and $5.50 \mathrm{mg}^{-\mathrm{g}^{-1}} \mathrm{DW}$ (secoisolariciresinol diglucoside), and neolignans at concentrations of $21.6 \mathrm{mg}^{-1}$ DW (dehydrodiconiferyl alcohol glucoside) and $4.9 \mathrm{mg} \mathrm{g}^{-1}$ DW (Guaiacylglycerol-ß-coniferyl alcohol ether glucoside). The formation of lignans was also investigated in hairy root cultures of Linum album. Lalaleo et al. (2018) reported the accumulation of nearly $60 \mu \mathrm{g} \cdot \mathrm{g}^{-1} \mathrm{DW}$ podophyllotoxin and $9.5 \mathrm{mg}^{-1} \mathrm{~g}^{-1} \mathrm{DW}$ 6-methoxypodophyllotoxin, these were about half the levels of those found in adventitious roots of L. album, as mentioned earlier. Ahmadian Chashmi and co-authors (2016) studied the formation of lignans in feeding experiments with hairy root cultures of L. album. After addition of $2 \mathrm{mM}$ coniferylaldehyde they detected $107.61 \mu \mathrm{ggg}^{-1} \mathrm{FW}$ lariciresinol, $8.7 \mu \mathrm{g} \cdot \mathrm{g}^{-1}$ FW pinoresinol, and $6.42 \mu \mathrm{gg}^{-1} \mathrm{FW}$ podophyllotoxin. The alpine plant Edelweiss (Leontopodium nivale ssp. alpinum) contains, amongs other compounds, the bioactive lignan leoligin at concentrations of $0.05-0.1 \mathrm{mg}^{-1} \mathrm{~g}^{-1} \mathrm{DW}$ (Wawrosch et al. 2013). Elicitation of a hairy root line of Edelweiss with $6 \%$ sucrose resulted in accumulation of $0.678 \mathrm{mg}^{-1} \mathrm{~g}^{-1}$ DW leoligin (Wawrosch et al. 2014).

Research on the in vitro production of lignans, especially of podophyllotoxin as important starting product for the semi-synthetic manufacture of anti-cancer drugs, stretches back several decades (Ionkova 2007). Notably, cell suspension cultures of Linum album were shown to accumulate up to $0.5 \%$ lignans, with podophyllotoxin as major compound (Smollny et al. 1998). A cell culture of Linum nodiflorum even accumulated 1.7\% DW of 6-methoxypodophyllotoxin (Kuhlmann et al. 2002). In view of these early reports, the recent findings quoted above do not represent a progress towards significantly increased lignan production in plant tissue cultures.

\section{Terpenoids}

Isoprenoids or terpenoids are ubiquitous natural compounds found in most organisms, with the majority occurring in plants. Terpenoids show manifold biological activities and are used pharmaceutically and as additives to food 
and cosmetic products (Sticher 2007b; Tetali 2019). The sesquiterpene lactone, artemisinin, is an important antimalaria drug occurring at low levels in sweet wormwood, Artemisia annua L. Due to the high demand for this compound and the complex total chemical synthesis, alternative sources including in vitro cultures of $A$. апnиа are being sought (Ali et al. 2017). Recently, Zebarjadi et al. (2018) could enhance the formation of artemisinin in cell suspension cultures of $A$. аппиа to $10.86 \mathrm{mg}^{-1} \mathrm{DW}$ through elicitation with abscisic acid. Similarly, Salehi and co-authors (2019a) reported a production of $9.33 \mathrm{mg} \mathrm{L}-1$ upon elicitation with coronatine and sorbitol. However, in both cases the previously reported yield of $110.2 \mathrm{mg} \mathrm{L}^{-1}$ (Baldi and Dixit 2008) could not be surpassed. The high productivity reported by Baldi and Dixit (2008) was based on a biomass production of $15.2 \mathrm{~g} \cdot \mathrm{L}^{-1}$ which was approx. fourfold higher than the one achieved by Salehi et al. (2019a). In addition, Baldi and Dixit (2008) combined elicitation (methyl jasmonate) with precursor feeding (mevalonic acid lactone). Patra and Srivastava (2016) investigated artemisinin formation in A. аппиа hairy roots cultivated in bioreactors. Through a combination of submerged growth in liquid medium for 5 days, followed by 15 days in a nutrient mist reactor, the obtained a yield of $1.12 \mathrm{mg} \cdot \mathrm{g}^{-1} \mathrm{DW}$, equivalent to $25.78 \mathrm{mg} \cdot \mathrm{L}^{-1}$ artemisinin. Due to the importance of this antimalaria drug, research into efficient production methods of artemisinin is promoted since decades (see, e.g., reviews by Wani et al. 2021; Badshah et al. 2018; Ikram and Simonsen 2017). While much higher production rates than in plant cell and organ cultures have been achieved in microbial systems (see below), the biotechnological production of artemisinin cannot yet compete with the large-scale extraction from $A$. апnиа plant material.

Paclitaxel (Taxol@) is an indispensable anti-cancer drug originally prepared from the bark of the Pacific yew (Taxus brevifolia Nutt). Due to the low content in the natural source, over the past decades alternative sources for this diterpenoid compound were developed, and since several years cell suspension cultures of Taxus species are used for the industrial production of paclitaxel and related compounds (McElroy and Jennewein 2018). Attempts to increase the in vitro yields of paclitaxel are still ongoing. SykłowskaBaranek et al. (2019) investigated paclitaxel formation in two hairy root lines of Taxus x media, one of which harbored a gene for taxadiene synthase (TXS). In their study they evaluated the effects of various elicitor treatments and a perfluorodecalin-supported two liquid-phase culture system on product formation and expression pattern of three paclitaxel biosynthetic genes. The authors reported a yield of $2.47 \mathrm{mg} \cdot \mathrm{g}^{-1}$ DW paclitaxel in the TXS-harboring hairy root line upon elicitation with $100 \mu \mathrm{M}$ methyl jasmonate, $10 \mu \mathrm{M}$ sodium nitroprusside, $100 \mu \mathrm{M} \mathrm{L}$-phenylalanine, and
$30 \mathrm{~g} \cdot \mathrm{L}^{-1}$ sucrose, with a degassed perfluorodecalin phase. By comparison, $0.378 \mathrm{mg}^{-1} \mathrm{~g}^{-1} \mathrm{DW}$ paclitaxel and a total taxane content of $1.59 \mathrm{mg} \mathrm{g}^{-1} \mathrm{DW}$ were detected in the needles of one out of 17 screened cultivars of Taxus x media (Wang et al. 2006). Through co-culture of Corylus avellana (hazelnut) cells with the endophytic paclitaxel-producing fungus Epicoccum nigrum strain $\mathrm{YEF}_{2}$ Salehi and co-authors (Salehi et al. 2019b) achieved the production of $404.5 \mu \mathrm{g} \mathrm{L}^{-1}$ paclitaxel, which was significantly more than in the control monocultures. Farhadi et al. (2020) demonstrated that elicitation of a hazelnut cell suspension culture with a cell wall preparation of Coniothyrium palmarum, together with the application of methyl- $\beta$-cyclodextrin to enhance product secretion into the culture medium, led to the formation of $402.4 \mu \mathrm{g} \cdot \mathrm{L}^{-1}$ paclitaxel. This was a nearly sixfold increase when compared to the untreated control. Hairy root cultures of Corylus avellana have been studied by Jalalipour Parizi et al. (2020). They evaluated three A. rhizogenes strains and six culture media and obtained a maximum yield of $3.2 \mu \mathrm{g}^{-1}{ }^{-1} \mathrm{DW}$ paclitaxel. The current knowledge about paclitaxel, including its biotechnological production, has recently been reviewed by McElroy and Jennewein (2018). Nearly two decades ago suspension cultures of Taxus chinensis were reported to yield $565 \mathrm{mg} \mathrm{L}^{-1}\left(29.3 \mathrm{mg}^{-1} \mathrm{DW}\right)$ paclitaxel upon repeated elicitation with methyl jasmonate in a bioreactor (Wang and Zhong 2002). Hence, the productivity of the in vitro systems reported in the recent studies quoted above was far from the yields achieved in 2002.

Ginseng (Panax ginseng C.A. Meyer and other Panax species) is an important medicinal plant widely used in Asian countries since a long time, with increasing popularity in many other countries. Because of the time-consuming and laborious field cultivation biotechnological strategies for the production of ginsenosides, the main ginseng compounds, have been investigated for a considerable time (Wu and Zhong 1999; Murthy et al. 2014). Since 1988 ginseng cells are cultivated on an industrial scale in Japan for the production of ginsenosides (Hibino and Ushiyama 1999). Le et al. (2019) investigated ginsenoside formation in longterm (20 years) and short-term (1 year) suspension cultures of $P$. ginseng and compared the accumulation profiles of the main compounds of the protopanaxadiol and protopanaxatriol types. At different time points of the cultivation period they found total ginsenoside contents to range from 4.70 to $8.00 \mathrm{mg} \cdot \mathrm{g}^{-1} \mathrm{DW}$ in short-term cultures and from 2.62 to $9.04 \mathrm{mg} \mathrm{g}^{-1}$ DW in long-term cultures. Murthy et al. (2018) reported the commercial production of $P$. ginseng adventitious roots in South Korea, which yield up to $32.46 \mathrm{mg} \cdot \mathrm{g}^{-1}$ DW ginsenosides; according to the authors the annual production of root biomass amounts to 45 tons and is used in the pharmaceutical, food and cosmetic industry. The influence of various abiotic and biotic elicitors on ginsenoside formation in cell suspensions of $P$. quinquefolius was investigated 
by Biswas et al. (2016). The elicitor treatments were found to differentially impact total ginsenoside content, proportions of protopanaxadiols and protopanaxatriols, and the extent of product secretion into the culture medium. While the highest productivity $\left(87.6 \mathrm{mg} \mathrm{L}^{-1}\right)$ was achieved upon a five-day treatment with a culture filtrate of Trichoderma atroviridae, a 15-day elicitation with Trichoderma harzianum led to maximum biosynthesis and secretion of ginsenoside Rh1, a compound with well-studied antioxidant, anti-inflammatory, immunomodulatory activities, and positive effects on the nervous system (Tam et al. 2018). In another ginseng species (P. sikkimensis) Biswas and co-authors (2018) studied the effects of elicitation with preparations of two bacterial and two fungal strains on ginsenoside biosynthetic genes and product formation. They achieved a yield of $222.2 \mathrm{mg} \mathrm{L}{ }^{-1}$ ginsenosides upon elicitation of cell suspensions with culture filtrate of the fungus T. harzianum. As mentioned above, ginseng is a highly popular plant in Asian countries. Studies on the in vitro production started in the 1960s and numerous papers have been published since. In terms of ginsenoside production, an excellent yield of ca. $1.5 \mathrm{gL}^{-1}$ with suspension cultures of $P$. notoginseng has already been reported more than 20 years ago (Zhang and Zhong 1997).

The solanaceous plant Withania somnifera, as well as other members of the family used medicinally in the Indian Ayurvedic medicinal system, contains up to $0.5 \%$ withanolides, biologically active steroidal lactone triterpenoids. The withanolide accumulation in various in vitro cultures has been investigated, and the formation of $14.2 \mathrm{mg} \cdot \mathrm{g}^{-1}$ DW withanolides in cell suspension cultures of $W$. somnifera upon elicitation with a culture filtrate of Piriformospora indica has been reported by Ahlawat et al. (2017). In comparison, by combining elicitation with chitosan and precursor feeding (squalene) Sivanandhan et al. (2014) had achieved the production of $27.49 \mathrm{mg} \cdot \mathrm{g}^{-1} \mathrm{DW}$ withanolides. However, the withanolide content in the intact plant can vary considerably between 0.001 to $0.5 \%$ (Mirjalili et al. 2009), hence product formation rate in a cell suspension culture could also depend on the respective properties of the donor plant.

The pentacyclic triterpenoids, betulinic acid, oleanolic acid, and ursolic acid, are important raw materials for the preparation of semi-synthetic drugs, as has recently been reviewed for betulinic acid (Borkova et al. 2018). Upon elicitation with culture medium filtrate of Aspergillus niger, combined with sucrose fed-batch, Kümmritz et al. (2016) obtained 5.76 and $10.77 \mathrm{mg}^{\cdot-1}$ DW oleanolic acid and ursolic acid, respectively, in suspension cultures of Salvia fruticosa. This was about $1 / 2$ and $1 / 3$ of the content found in the intact plants (Kümmritz et al. 2014). Lantana camara L. (Verbenaceae) is a popular ornamental plant which, however, is also known as a notorious weed. It has been used since a long time as medicinal plant in various parts of the world (Ghisalberti 2000). Kumar et al. (2016) investigated the accumulation of triterpenoids in suspension cultures of L. camara after elicitation with the root endophytic fungus Piriformospora indica. As stated by the authors, this was part of a study of the elicitor potential of the fungus. Treatment with a filter-sterilized culture filtrate of the fungus resulted in the formation of $117.02 \mu \mathrm{g} \cdot \mathrm{g}^{-1} \mathrm{DW}$ betulinic acid, $1.4 \mathrm{mg}^{-1}$ DW oleanolic acid, and $3.87 \mathrm{mg}^{-1} \mathrm{~g}^{-1} \mathrm{DW}$ ursolic acid. Basically, the suitability of betulinic acid as a target compound for in vitro production has to be critically assessed. An efficient strategy for the preparation of the compound from plant raw material has recently been communicated by Ressmann et al. (2017). The precursor triterpenoid betulin is found in the bark of white birch in quantities up to $35 \%$. Huge amounts of birch bark accumulate as by-product from pulp and paper mills, and while the conventional conversion of betulin to betulinic acid is problematic (low yield, toxic reagents), Ressmann et al. (2017) developed a quick extraction procedure for betulin at room temperature, followed by direct oxidation of the crude extract without using toxic reagents.

The flower heads of marigold (Calendula officinalis, Asteraceae) are used for the treatment of skin irritations and to promote wound healing. Besides other metabolites they also contain up to $10 \%$ triterpene saponins (Lichius et al. 2016). The accumulation of oleanolic acid glycosides in hairy roots of marigold was studied by Alsoufi et al. (2019). Elicitation with $100 \mu \mathrm{M}$ jasmonic acid resulted in dramatic increase in productivity.

The medicinal use of Ginkgo biloba has been described ca. 5000 years ago in the Chinese pharmacopoeia Chen Noung Pen Tsao, and nowadays its efficacy in the treatment of Alzheimer's disease, vascular dementia and other ailments is established (Volk et al. 2016). In a recent study Sukito and Tachibana (2016) investigated the productivity of ginkgo cells immobilized on jute fibers, combined with methyl jasmonate and salicylic acid elicitation. Production of $78 \mathrm{mg} \cdot \mathrm{g}^{-1}$ DW bilobalide, $79 \mathrm{mg} \cdot \mathrm{g}^{-1}$ DW ginkgolide A, $71 \mathrm{mg}^{-1} \mathrm{DW}$ ginkgolide $\mathrm{B}$, and $7.5 \mathrm{mg}^{-1} \mathrm{~g}^{-1} \mathrm{DW}$ ginkgolide $\mathrm{C}$ could be achieved.

The Asteraceae Stevia rebaudiana is a well-known herb with an intensely sweet taste which is used to prepare sweeteners for home and commercial purposes. The leaves contain up to $10 \%$ of the diterpene glycoside, stevioside, as well as up to $4 \%$ rebaudioside A, $2 \%$ rebaudioside $\mathrm{C}$, and $0.7 \%$ dulcoside as sweet tasting compounds (Blaschek and Loew 2016). Ahmad et al. (2018) investigated the influence of $\mathrm{pH}$ levels on product formation in adventitious root cultures. They found that lower $\mathrm{pH}$ (5.1) promoted the formation of stevioside $\left(79.48 \mathrm{mg} \mathrm{g}^{-1} \mathrm{DW}\right)$ and rebaudioside A $\left(13.10 \mathrm{mg}^{-1} \mathrm{DW}\right)$, while dulcoside could not be detected. At higher $\mathrm{pH}$ of 5.8 the concentration of the two former metabolites was significantly lower, but $2.57 \mathrm{mg}^{-1} \mathrm{DW}$ 
dulcoside were found. However, the $\mathrm{pH}$ level also influenced root growth, at $\mathrm{pH} 6.0$ the highest biomass was observed. It is however questionable whether a production of steviosides through plant tissue culture would ever be competitive to the extraction from the plant, given the high content of up to $10 \%$ in the leaves.

The perennial herb Hybanthus enneaspermus is used in the Ayurveda medicinal system for the treatment of various disorders, like, e.g., urinary infections, dysentery, or cough (Patel et al. 2013). One of the secondary metabolites found in this plant is L-Dopa (L-3,4-dihyroxyphenylalanine) which is an important drug for the treatment of Parkinson's disease. Sathish et al. (2020) investigated the effects of elicitors on the accumulation of L-Dopa in adventitious roots of H. enneaspermus. A treatment of the cultures with $100 \mu \mathrm{M}$ salicylic acid resulted in the formation of $12.64 \mathrm{mg}^{-1} \mathrm{DW}$ L-Dopa. The authors suggested that adventitious root cultures of $H$. enneaspermus could be used for the industrial production of L-Dopa, it is however disputable whether this would be an alternative to microbial fermentation which exhibits considerably higher productivity (Min et al. 2015).

While the low productivity of cell suspension cultures remains a challenge, these recent studies show that upon proper optimization of suitable cell lines it is possible to achieve levels of secondary metabolites equal to or even higher than those found in the intact plant. Hence, considering the various advantages of biotechnological production of natural products, ongoing research in the field of plant cell suspension cultures remains an important task.

\section{Plant metabolic engineering}

Plant metabolic engineering as relevant to bioactive secondary metabolites aims at increasing the accumulation of a desired product, or/and at reducing accumulation of an undesired metabolite. This can be achieved by overexpression of enzymes, either in upstream pathways, or in the target compound pathway; by increasing the activity of ratelimiting enzymes; by suppression of competing pathways or catabolic steps; and by creating sink compartments that store the desired metabolite (Farré et al. 2014). The modification of the tropane alkaloid pattern in Atropa belladonna was the first proof of concept for the successful metabolic engineering of medicinal plants. Through overexpression of $h 6 h$, the gene coding for hyoscyamine 6- $\beta$ hydroxylase which catalyzes the final steps in the biosynthesis of scopolamine, Yun et al. (1992) obtained A. belladonna plants with significantly elevated scopolamine content. Some of the most recent studies dealing with metabolically engineered plant in vitro cultures are summarized below.

Several studies with alkaloid-containing Solanaceae plants have shown that undifferentiated plant in vitro cultures like callus and cell suspensions do not accumulate significant amounts of tropane alkaloids (Kohnen-Johannsen and Kayser 2019). This is, however, not the case with hairy roots, and the transformation process with A. rhizogenes can also be utilized for metabolic engineering purposes. Species of the genus Duboisia are cultivated for the extraction of scopolamine, but besides tropane alkaloids, the roots of Duboisia species also synthesize nicotine and related pyridine alkaloids. Singh et al. (2018) demonstrated that RNAi silencing of the quinolinate phosphoribosyl transferase gene in the nicotine biosynthetic pathway led to significant inhibition of nicotine biosynthesis and enhanced formation of scopolamine. Upon elicitation of such a hairy root line with methyl jasmonate the production of $19.34 \mathrm{mg} \mathrm{g}^{-1}$ DW scopolamine was achieved, compared to $1.44 \mathrm{mgg}^{-1} \mathrm{DW}$ in the non-elicited wild type control line. In order to enhance the formation of the anticancer alkaloid camptothecin in hairy roots of Ophiorrhiza pumila, Shi et al. (2020) established a transgenic root line overexpressing geraniol-10-hydroxylase and secologanin synthetase genes. While under optimized culture conditions camptothecin production in stem and roots of up to $2 \mathrm{mg} \mathrm{g}^{-1}$ DW has been reported (Lee et al. 2020), the engineered hairy root line yielded $3.5 \mathrm{mgg}^{-1}$ of the compound.

Biosynthesis of the pharmaceutically important terpenoid indole alkaloids (TIAs) in Madagascar periwinkle $(C$. roseus) involves a pathway of more than 35 enzymatic steps in different cellular and subcellular compartments (Sharma et al. 2020). Saiman et al. (2018) overexpressed the $C$. roseus geraniol synthase gene in either plastids or cytosol of a non-alkaloid producing $C$. roseus cell line. These cell lines produced TIAs upon elicitation with jasmonic acid, which indicated that other, inducible genes need to be expressed, too. The authors also found that alterations in the primary metabolism occurred, so that further studies are necessary to understand the full effects of their metabolic engineering approach. Sharma et al. (2018) introduced additional copies of the tryptophan decarboxylase and strictosidine synthase genes into $C$. roseus callus and achieved a doubled total alkaloid content of $1.2 \mathrm{mg}^{-1} \mathrm{DW}$, when compared to the untransformed control. Sun and Peebles (2016) established C. roseus hairy roots overexpressing the transcriptional regulator ORCA3 (octadecanoid responsive Catharanthus AP2-domain protein) gene and the strictosidine glucosidase gene, which resulted in $47 \%$ increase in the content of six root-specific TIAs. In a different approach, overexpression of the CrTPT2 (a ATP-binding cassette transporter for catharanthine) gene in C. roseus hairy roots increased the accumulation of catharanthine to ca. $5 \mathrm{mg}^{-1} \mathrm{~g}^{-1} \mathrm{DW}$, which was fivefold higher than in the wild type control roots (Wang et al. 2019).

An efficient plant cell-based production system for anthocyanins has been reported by Appelhagen et al. (2018). 
They established suspension cultures from a transgenic line of Nicotiana tabacum which constitutively expressed the AmRos1 and AmDel transcription factors from Antirrhinum majus (Kallam et al. 2017). These cells produced $30 \mathrm{mg} \cdot \mathrm{g}^{-1}$ DW cyanidin 3-O-rutinoside and this biosynthetic potential remained stable over a 10 -years observation period. Upon additional introduction of a gene encoding flavonoid 3',5'-hydroxylase from Petunia x hybrida, the resulting cell suspension culture was shown to produce cyanidin 3-O-rutinoside and also delphinidin 3-O-rutinoside. Engineering of a gene encoding an anthocyanin 3-O-rutinoside-4"'hydroxycinnamoyl transferase from Solanum lycopersicum into the AmRos1/AmDel tobacco line led to the formation of acylated anthocyanins. The authors thereby demonstrated the potential of their system for the production of a variety of highly-decorated anthocyanins.

The abovementioned studies stress the importance of understanding the biosynthetic pathways for plant secondary metabolites in order to rationally manipulate them. In addition, understanding of pathway regulation, which can be very complex, is also required for optimal metabolic engineering of plants toward enhanced production of medicinally important compounds. For more detailed information, the reader is referred to relevant literature like, e.g., the recent review by Birchfield and McIntosh (2020).

\section{Heterologous production in microorganisms}

Notwithstanding the fact that high yielding cell suspension and organ lines can be established for a variety of plants, plant tissue cultures suffer from a number of disadvantages that limit the large-scale commercial application to but a few processes. Cell suspension cultures often exhibit slow growth and frequently are genetically unstable, which results in unreliable productivity. Organ cultures are even slower in growth, and the large-scale cultivation especially of (hairy) root cultures is technically challenging and expensive. In contrast, microbial systems feature rapid growth, are readily scalable to established fermentation and downstream processes, and protocols for their genetic manipulation are readily available. Purification of the product is easier, and the production process is cost-effective because inexpensive feedstock can be utilized for fermentation media (Moses et al. 2017). This section highlights recent examples of the heterologous production of bioactive plant secondary metabolites in microbial hosts.

The indole alkaloid psilocybin is a psychoactive secondary metabolite from hallucinogenic mushrooms with very promising therapeutic properties for the treatment of depression, post-traumatic stress disorder, or addiction. In 2017 four psilocybin biosynthetic enzymes were characterized and an enzymatic synthesis of this metabolite from 4-hydroxy-1-tryptophan was reported (Fricke et al. 2017). Subsequently, Hoefgen et al. (2018) achieved psilocybin titers of up to $110 \mathrm{mg} \mathrm{L}^{-1}$ through heterologous expression of the biosynthetic genes in Aspergillus nidulans. In the most recent study, a modular biosynthetic production platform in Escherichia coli was constructed, and after fermentation optimization a production titer of $1.16 \mathrm{~g} \mathrm{~L}^{-1}$ psilocybin by bioconversion of the precursors 4-hydroxyindole, serine and methionine was reported by Adams et al. (2019). Complete de novo production of psilocybin and related tryptamine derivatives in Saccharomyces cerevisiae was achieved by Milne et al. (2020). After introduction of five heterologous genes (tryptophan decarboxylase from Catharanthus roseus and four genes from Psilocybe cubensis) into yeast, followed by further engineering of genes in the shikimate pathway and optimization of fed-batch fermentation, the yeast strain yielded $627 \mathrm{mg} \mathrm{L}^{-1}$ psilocybin and $580 \mathrm{mg} \cdot \mathrm{L}^{-1}$ psilocin, the latter being the bioactive metabolite of psilocybin which is formed in humans from orally administered psilocybin.

Noscapine is one of the main alkaloids of opium poppy (Papaver somniferum). It is used as antitussive drug and has been shown to possess promising anticancer properties (DeBono et al. 2015). An engineered strain of $S$. cerevisiae was constructed containing 25 heterologous plant, mammalian and bacterial genes, and 6 overexpressed or mutant yeast genes. Through a combination of enzyme engineering, pathway and strain engineering, and fermentation optimization, a noscapine titer of $2.21 \mathrm{mg} \mathrm{L}^{-1}$ could be achieved (Li et al. 2018). Notably, halogenated benzylisoquinolide alkaloids could be obtained by feeding modified tyrosine derivatives, which may lead to novel structures for drug development.

Kallscheuer et al. (2016) described the construction of a Corynebacterium glutamicum strain for the production of plant polyphenols. After deletion of genes involved in the catabolism of aromatic compounds, and expression of plantderived genes coding for a chalcone synthase and a chalcone isomerase, they achieved the production of $35 \mathrm{mg} \cdot \mathrm{L}^{-1}$ naringenin and $37 \mathrm{mgL}^{-1}$ eriodictyol from supplemented phenylpropanoids p-coumaric acid and caffeic acid, respectively. Upon further engineering of the amino acid metabolism they obtained strains which produced of $32 \mathrm{mg} \mathrm{L}^{-1}$ naringenin or $59 \mathrm{mg} \mathrm{L}^{-1}$ resveratrol, directly from glucose. In a further development of these strains, introduction of plant-derived dioxigenase genes into the flavanone producing strain enabled the production of $23 \mathrm{mg} \cdot \mathrm{L}^{-1}$ kaempferol and $10 \mathrm{mg} \cdot \mathrm{L}^{-1}$ quercetin. Similarly, by expression of a modified O-methyltransferase from grapevine in the previously engineered resveratrol producer, Kallscheuer and co-authors (Kallscheuer et al. 2017) achieved a titer of $42 \mathrm{mg} \cdot \mathrm{L}^{-1}$ of the di-O-methylated compound pterostilbene.

Li et al. (2019) developed co-cultures of multiple engineered E. coli strains (modular co-culture engineering) for the production of rosmarinic acid. They divided the 
rosmarinic acid biosynthesis in three modules, namely caffeic acid, salvianic acid A, and rosmarinic acid module, which were engineered into separate E. coli strains. After optimization of strain-to-strain ratios and culture conditions, the production of $172 \mathrm{mg} \mathrm{L}^{-1}$ rosmarinic acid was achieved, which was a 38 -fold improvement over the parent strain used for monoculture-based biosynthesis. Acetylsalicylic acid (aspirin), a most prominent nonsteroidal anti-inflammatory drug, is produced industrially through acetylation of salicylic acid. Starting from an engineered salicylic acid producing E. coli strain, Ahmadi et al. (2016) further introduced a codon-optimized glucosyltransferase gene from Arabidopsis thaliana. By a coculture of two engineered strains the authors achieved a titer of ca. $2.5 \mathrm{~g} \mathrm{~L}^{-1}$ salicylate $2-\mathrm{O}-\beta$-D-glucoside, which showed nitric oxide and reactive oxygen species reducing activities comparable to aspirin.

Hemp (Cannabis sativa $\mathrm{L}$.) is one of the oldest crop plants on earth and has been used medicinally before being classified as illegal psychoactive drug. However, the therapeutic potential of some of its secondary metabolites, especially $\Delta 9$-tetrahydrocannabinol and cannabidiol, has been recognized and drugs for the treatment of multiple sclerosis symptoms as well as some forms of pediatric epilepsy have been approved (Cristino et al. 2020). In the cannabinoid biosynthesis, geranyl diphosphate and olivetolic acid are initial precursors which are condensed to cannabigerolic acid (CBGA). This intermediate is further converted to cannabidiolic acid (CBDA), $\Delta$ 9-tetrahydrocannabinolic acid ( $\Delta 9$-THCA) and cannabichromenic acid (CBCA) (Flores-Sanchez and Verpoorte 2008). In their attempts to establish a platform for the heterologous production of cannabinoids in yeasts, Zirpel et al. (2015) initially showed that Pichia pastoris expressing $\triangle 9$-THCA synthase from $C$. sativa produced $\triangle 9$-THCA from CBGA in a whole cell bioconversion assay. Subsequently, this yeast strain was further engineered with the prenyltransferase NphB from Streptomyces sp. strain CL190 and was shown to produce $\triangle 9$-THCA when supplemented with olivetolic acid and geranyl diphosphate (Zirpel et al. 2017). The complete biosynthesis of cannabinoids, and also of unnatural cannabinoid analogues, in engineered $S$. cerevisiae has been recently reported by Luo et al. (2019). This was accomplished by introducing a heterologous hexanoylCoA biosynthetic pathway, and providing a high flux of geranyl diphosphate by engineering the native mevalonate pathway. Furthermore, Cannabis genes for the biosynthesis of olivetolic acid, as well as genes for cannabinoid synthases were introduced. With an optimized strain, titers of $8 \mathrm{mg} \mathrm{L}^{-1}$ $\Delta 9$-THCA were obtained. The authors also demonstrated that different fatty acid precursors were incorporated into corresponding olivetolic acid, CBGA and $\triangle 9$-THCA analogues. Such unnatural cannabinoids are of great interest because of potentially improved medicinal properties (Luo et al. 2019).
Heterologous production of the antimalarial drug artemisinin in microbial hosts has been intensely investigated and in 2013 led to the commercialization of "semi-synthetic artemisinin": the precursor artemisinic acid was produced with an engineered strain of S. cerevisiae at $25 \mathrm{~g} \mathrm{~L}^{-1}$ and then chemically converted to artemisinin (Kung et al. 2018). However, the process was not viable because of the then lower price of plant-derived drug in the fluctuating artemisinin market (Peplow 2016). In their search for alternative microbial hosts for artemisinin production, Marsafari and $\mathrm{Xu}$ (2020) chose the yeast Yarrowia lipolytica which they engineered to accumulate amorphadiene, which is the direct sesquiterpene precursor of artemisinin. Upon introduction of the codon-optimized A. апnиа amorphadiene synthase gene, the initially low amorphadiene titer could be increased to $171.5 \mathrm{mg} \mathrm{L}^{-1}$ by introducing additional copies of some mevalonate pathway genes and inhibiting fatty acids synthesis.

Several recent studies dealt with the heterologous production of plant triterpenoids. Wang et al. (2020) constructed a synthetic biology platform to elucidate the saponin biosynthesis pathway of Panax notoginseng. Subsequently, they engineered a yeast cell factory that yielded $1.17 \mathrm{gL}^{-1}$ of ginsenoside compound $\mathrm{K}$, an anticarcinogenic and antiinflammatory secondary metabolite, the content of which is quite low in ginseng. Plants of the Cucurbitaceae family are widely used in Asian traditional medicine to treat various types of cancers, as well as inflammatory diseases. They contain cucurbitane-type triterpenoid glycosides derived from cucurbitadienol, which itself also has anticancer and anti-inflammatory properties ( $\mathrm{Li}$ et al. 2017). A synthetic pathway for cucurbitadienol biosynthesis was constructed in S. cerevisiae by Qiao et al. (2019). Firstly, they introduced the cucurbitadienol synthase gene from the Cucurbitaceae plant Siraitia grosvenorii into a yeast strain with high squalene content. Subsequently, several genes involved in squalene biosynthesis were overexpressed, as squalene is a precursor in triterpene biosynthesis. Finally, the metabolic flux to ergosterol was downregulated through knockout of the ERG7 gene, thus resulting in the production of $63 \mathrm{mg} \mathrm{L}{ }^{-1}$ cucurbitadienol in fed-batch fermentation of the optimized yeast strain. Enhanced heterologous production of another triterpenoid, oleanolic acid, has been accomplished in yeast by Zhao et al. (2018). Three plant genes, namely a $\beta$-amyrin synthase gene from Glycyrrhiza glabra, an oleanolic acid synthase gene from Medicago truncatula, and a cytochrome $\mathrm{P} 450$ reductase gene from M. truncatula, were expressed in S. cerevisiae JDY52, thus resulting in the synthesis of oleanolic acid. Subsequently, overexpression of three genes of the yeast native ergosterol pathway, knockout of two genes involved in the galactose regulatory network, and optimization of the fermentation conditions resulted in a titer of $606.9 \mathrm{mg} \mathrm{L}^{-1}$ oleanolic acid. 


\section{Conclusions}

For the industrial production of plant secondary metabolites, plant cell and organ culture provides a controllable, environmentally friendly, and sustainable alternative to laborious field cultivation. The large number of studies on the in vitro production of bioactive plant compounds published in the past few years indicates the unabated importance of relevant research. Factors like culture techniques or impact of elicitation on gene expression appear to be of outmost importance, and for a number of medicinal plants cell or organ cultures producing higher amounts of relevant metabolites than the respective plant have been reported. While many authors emphasize the suitability of their in vitro systems for the commercial production of the respective compound, such claims should be considered with care. Even after decades of research resulting in many high yielding cell suspension and organ culture lines, to date only one process, namely the production of paclitaxel by Taxus cell cultures, is deployed on an industrial scale. Quite a number of the recently published studies deal with secondary compounds which have been the subject of intense investigations since roughly 50 years, and highly productive in vitro systems have been published decades ago. Yet, although these processes were clearly superior to recently published systems, they have never been commercialized. In this view, it has to be realized that in most cases progress towards increased productivity of plant based in vitro systems is lacking.

A number of critical factors which determine the commercialization of plant in vitro production systems have to be considered, such as market prices (both of the pure compound, and of the raw material used for extraction of the compound), economical feasibility of chemical synthesis, regulatory requirements, and consumer acceptance. Both the market situation and the clinical demand for certain plant secondary metabolites are prone to changes (Lange 2018; Kreis 2019), and the extent of ongoing research as reviewed here demonstrates the potential of plant in vitro cultures for the production of bioactive secondary metabolites. Without a doubt, the metabolic engineering of plants and heterologous production in microorganisms are very promising approaches, that heavily depend on the elucidation of biosynthetic pathways, synthetic biology tools and progress in genome engineering. Especially the construction of microbial cell factories can be expected to render a cost-efficient production of bioactive plant secondary metabolites possible.

Author contribution CW and SBZ outlined the manuscript. CW surveyed the literature and drafted the article. Both authors read and approved the final version of the manuscript.
Funding Open access funding provided by University of Vienna. This work was supported by the University of Vienna.

Data availability Not applicable.

Code availability Not applicable.

\section{Declarations}

Ethics approval Not applicable.

Conflict of interest The authors declare no competing interests.

Open Access This article is licensed under a Creative Commons Attribution 4.0 International License, which permits use, sharing, adaptation, distribution and reproduction in any medium or format, as long as you give appropriate credit to the original author(s) and the source, provide a link to the Creative Commons licence, and indicate if changes were made. The images or other third party material in this article are included in the article's Creative Commons licence, unless indicated otherwise in a credit line to the material. If material is not included in the article's Creative Commons licence and your intended use is not permitted by statutory regulation or exceeds the permitted use, you will need to obtain permission directly from the copyright holder. To view a copy of this licence, visit http://creativecommons.org/licenses/by/4.0/.

\section{References}

Açıkgöz MA (2020) Establishment of cell suspension cultures of Ocimum basilicum $\mathrm{L}$. and enhanced production of pharmaceutical active ingredients. Ind Crops Prod 148:112278. https://doi.org/ 10.1016/j.indcrop. 2020.112278

Adams AM, Kaplan NA, Wei Z, Brinton JD, Monnier CS, Enacopol AL, Ramelot TA, Jones JA (2019) In vivo production of psilocybin in E. coli. Metab Eng 56:111-119. https://doi.org/10.1016/j. ymben.2019.09.009

Ahlawat S, Saxena P, Ali A, Khan S, Abdin MZ (2017) Comparative study of withanolide production and the related transcriptional responses of biosynthetic genes in fungi elicited cell suspension culture of Withania somnifera in shake flask and bioreactor. Plant Physiol Biochem 114:19-28. https://doi.org/10.1016/j.plaphy. 2017.02.013

Ahmad N, Rab A, Ahmad N, Fazal H (2018) Differential pH-Induced Biosynthesis of Steviol Glycosides and Biochemical Parameters in Submerge Root Cultures of Stevia rebaudiana (Bert.). Sugar Tech 20:734-744. https://doi.org/10.1007/s12355-018-0589-z

Ahmadi MK, Fang L, Moscatello N, Pfeifer BA (2016) E. coli metabolic engineering for gram scale production of a plant-based antiinflammatory agent. Metab Eng 38:382-388. https://doi.org/10. 1016/j.ymben.2016.10.001

Ahmadian Chashmi N, Sharifi M, Behmanesh M (2016) Lignan enhancement in hairy root cultures of Linum album using coniferaldehyde and methylenedioxycinnamic acid. Prep Biochem Biotechnol 46:454-460. https://doi.org/10.1080/10826068.2015. 1068802

Albuquerque UP, Ramos MA, Melo JG (2012) New strategies for drug discovery in tropical forests based on ethnobotanical and chemical ecological studies. J Ethnopharmacol 140:197-201. https:// doi.org/10.1016/J.JEP.2011.12.042

Ali M, Abbasi BH, Ahmad N, Khan H, Ali GS (2017) Strategies to enhance biologically active-secondary metabolites in cell 
cultures of Artemisia - current trends. Crit Rev Biotechnol 37:833-851. https://doi.org/10.1080/07388551.2016.1261082

Alsoufi ASM, Pączkowski C, Szakiel A, Długosz M (2019) Effect of jasmonic acid and chitosan on triterpenoid production in Calendula officinalis hairy root cultures. Phytochem Lett 31:5-11. https://doi.org/10.1016/j.phytol.2019.02.030

Anjum S, Komal A, Drouet S, Kausar H, Hano C, Abbasi BH (2020) Feasible Production of Lignans and Neolignans in Root-Derived In Vitro Cultures of Flax (Linum usitatissimum L.). Plants 9:409. https://doi.org/10.3390/plants9040409

Appelhagen I, Wulff-Vester AK, Wendell M, Hvoslef-Eide A-K, Russell J, Oertel A, Martens S, Mock H-P, Martin C, Matros A (2018) Colour bio-factories: Towards scale-up production of anthocyanins in plant cell cultures. Metab Eng 48:218-232. https://doi.org/10.1016/j.ymben.2018.06.004

Atanasov AG, Waltenberger B, Pferschy-Wenzig E-M, Linder T, Wawrosch C, Uhrin P, Temml V, Wang L, Schwaiger S, Heiss EH, Rollinger JM, Schuster D, Breuss JM, Bochkov V, Mihovilovic MD, Kopp B, Bauer R, Dirsch VM, Stuppner H (2015) Discovery and resupply of pharmacologically active plant-derived natural products: A review. Biotechnol Adv 33:1582-1614. https:// doi.org/10.1016/j.biotechadv.2015.08.001

Atanasov AG, Zotchev SB, Dirsch VM, Orhan IE, Banach M, Rollinger JM, Barreca D, Weckwerth W, Bauer R, Bayer EA, Majeed M, Bishayee A, Bochkov V, Bonn GK, Braidy N, Bucar F, Cifuentes A, D’Onofrio G, Bodkin M, Diederich M, Dinkova-Kostova AT, Efferth T, El Bairi K, Arkells N, Fan T-P, Fiebich BL, Freissmuth M, Georgiev MI, Gibbons S, Godfrey KM, Gruber CW, Heer J, Huber LA, Ibanez E, Kijjoa A, Kiss AK, Lu A, Macias FA, Miller MJS, Mocan A, Müller R, Nicoletti F, Perry G, Pittalà V, Rastrelli L, Ristow M, Russo GL, Silva AS, Schuster D, Sheridan H, Skalicka-Woźniak K, Skaltsounis L, Sobarzo-Sánchez E, Bredt DS, Stuppner H, Sureda A, Tzvetkov NT, Vacca RA, Aggarwal BB, Battino M, Giampieri F, Wink M, Wolfender J-L, Xiao J, Yeung AWK, Lizard G, Popp MA, Heinrich M, Berindan-Neagoe I, Stadler M, Daglia M, Verpoorte R, Supuran CT, Taskforce the INPS (2021) Natural products in drug discovery: advances and opportunities. Nat Rev Drug Discov 20:200-216. https://doi.org/10.1038/s41573-020-00114-Z

Badshah SL, Ullah A, Ahmad N, Almarhoon ZM, Mabkhot Y (2018) Increasing the Strength and Production of Artemisinin and Its Derivatives. Molecules 23:100. https://doi.org/10.3390/molec ules23010100

Baldi A, Dixit VK (2008) Yield enhancement strategies for artemisinin production by suspension cultures of Artemisia annиa. Bioresour Technol 99:4609-4614. https://doi.org/10.1016/j.biortech.2007. 06.061

Balunas MJ, Kinghorn AD (2005) Drug discovery from medicinal plants. Life Sci 78:431-441. https://doi.org/10.1016/j.lfs.2005. 09.012

Barker D (2019) Lignans Molecules 24:1424. https://doi.org/10.3390/ molecules24071424

Bekiesch P, Oberhofer M, Sykora C, Urban E, Zotchev SB (2021) Piperazic acid containing peptides produced by an endophytic Streptomyces sp. isolated from the medicinal plant Atropa belladonna. Nat Prod Res 35:1090-1096. https://doi.org/10.1080/ 14786419.2019.1639174

Birchfield AS, McIntosh CA (2020) Metabolic engineering and synthetic biology of plant natural products - A minireview. Curr Plant Biol 24:100163. https://doi.org/10.1016/j.cpb.2020.100163

Biswas T, Kalra A, Mathur AK, Lal RK, Singh M, Mathur A (2016) Elicitors' influenced differential ginsenoside production and exudation into medium with concurrent $\mathrm{Rg} 3 / \mathrm{Rh} 2$ panaxadiol induction in Panax quinquefolius cell suspensions. Appl Microbiol Biotechnol 100:4909-4922. https://doi.org/10.1007/ s00253-015-7264-Z
Biswas T, Pandey SS, Maji D, Gupta V, Kalra A, Singh M, Mathur A, Mathur AK (2018) Enhanced expression of ginsenoside biosynthetic genes and in vitro ginsenoside production in elicited Panax sikkimensis (Ban) cell suspensions. Protoplasma 255:1147-1160. https://doi.org/10.1007/s00709-018-1219-Z

Blaschek W, Loew D (2016) Steviae rebaudianae folium. In: Blaschek W (ed) Wichtl - Teedrogen und Phytopharmaka, 6th edn. Wissenschaftliche Verlagsgesellschaft, Stuttgart, pp 626-627

Boller B, Schubiger FX, Kölliker R (2010) Red Clover. In: Boller B, Posselt UK, Veronesi F (eds) Fodder Crops and Amenity Grasses. Springer, New York, New York, NY, pp 439-455

Borkova L, Hodon J, Urban M (2018) Synthesis of Betulinic Acid Derivatives with Modified A-Rings and their Application as Potential Drug Candidates. Asian J Org Chem 7:1542-1560. https://doi.org/10.1002/ajoc.201800163

Brower V (2008) Back to Nature: Extinction of Medicinal Plants Threatens Drug Discovery. JNCI J Natl Cancer Inst 100:838839. https://doi.org/10.1093/jnci/djn199

Canel C, Moraes RM, Dayan FE, Ferreira D (2000) Podophyllotoxin Phytochemistry 54:115-120. https://doi.org/10.1016/S00319422(00)00094-7

Canter PH, Thomas H, Ernst E (2005) Bringing medicinal plants into cultivation: opportunities and challenges for biotechnology. Trends Biotechnol 23:180-185. https://doi.org/10.1016/J. TIBTECH.2005.02.002

Cardoso JC, de Oliveira MEBS, de Cardoso F, CI, (2019) Advances and challenges on the in vitro production of secondary metabolites from medicinal plants. Hortic Bras 37:124-132

Chandran H, Meena M, Barupal T, Sharma K (2020) Plant tissue culture as a perpetual source for production of industrially important bioactive compounds. Biotechnol Reports 26:e0450. https://doi.org/10.1016/j.btre.2020.e00450

Chávez-González ML, Sepúlveda L, Verma DK, Luna-García HA, Rodríguez-Durán LV, Ilina A, Aguilar CN (2020) Conventional and Emerging Extraction Processes of Flavonoids. Processes 8:434. https://doi.org/10.3390/pr8040434

Cheigh C-I, Chung E-Y, Chung M-S (2012) Enhanced extraction of flavanones hesperidin and narirutin from Citrus unshiu peel using subcritical water. J Food Eng 110:472-477. https://doi. org/10.1016/j.jfoodeng.2011.12.019

Chen J, Li W, Yao H, Xu J (2015) Insights into drug discovery from natural products through structural modification. Fitoterapia 103:231-241. https://doi.org/10.1016/J.FITOTE.2015.04.012

Cordell GA, Colvard MD (2005) Some thoughts on the future of ethnopharmacology. J Ethnopharmacol 100:5-14. https://doi. org/10.1016/J.JEP.2005.05.027

Cristino L, Bisogno T, Di Marzo V (2020) Cannabinoids and the expanded endocannabinoid system in neurological disorders. Nat Rev Neurol 16:9-29. https://doi.org/10.1038/ s41582-019-0284-z

DeBono A, Capuano B, Scammells PJ (2015) Progress Toward the Development of Noscapine and Derivatives as Anticancer Agents. J Med Chem 58:5699-5727. https://doi.org/10.1021/ jm501180v

Deepthi S, Satheeshkumar K (2017a) Effects of major nutrients, growth regulators and inoculum size on enhanced growth and camptothecin production in adventitious root cultures of Ophiorrhiza mungos L. Biochem Eng J 117:198-209. https://doi.org/10. 1016/j.bej.2016.10.016

Deepthi S, Satheeshkumar K (2017b) Cell line selection combined with jasmonic acid elicitation enhance camptothecin production in cell suspension cultures of Ophiorrhiza mungos L. Appl Microbiol Biotechnol 101:545-558. https://doi.org/10.1007/ s00253-016-7808-x

Dhiman N, Patial V, Bhattacharya A (2018) The Current Status and Future Applications of Hairy Root Cultures. In: Kumar N (ed) 
Biotechnological Approaches for Medicinal and Aromatic Plants: Conservation, Genetic Improvement and Utilization. Springer Singapore, Singapore, pp 87-155

Dziggel C, Schäfer H, Wink M (2017) Tools of pathway reconstruction and production of economically relevant plant secondary metabolites in recombinant microorganisms. Biotechnol J 12:1600145. https://doi.org/10.1002/biot.201600145

Fabricant DS, Farnsworth NR (2001) The value of plants used in traditional medicine for drug discovery. Environ Health Perspect 109:69-75. https://doi.org/10.1289/ehp.01109s169

Farhadi S, Moieni A, Safaie N, Sabet MS, Salehi M (2020) Fungal Cell Wall and Methyl- $\beta-$ Cyclodextrin Synergistically Enhance Paclitaxel Biosynthesis and Secretion in Corylus avellana Cell Suspension Culture. Sci Rep 10:5427. https://doi.org/10.1038/ s41598-020-62196-4

Farré G, Blancquaert D, Capell T, Van Der Straeten D, Christou P, Zhu C (2014) Engineering Complex Metabolic Pathways in Plants. Annu Rev Plant Biol 65:187-223. https://doi.org/10. 1146/annurev-arplant-050213-035825

Fattori V, Hohmann M, Rossaneis A, Pinho-Ribeiro F, Verri W (2016) Capsaicin: Current Understanding of Its Mechanisms and Therapy of Pain and Other Pre-Clinical and Clinical Uses. Molecules 21:844. https://doi.org/10.3390/molecules21070844

Flores-Sanchez IJ, Verpoorte R (2008) PKS Activities and Biosynthesis of Cannabinoids and Flavonoids in Cannabis sativa L. Plants Plant Cell Physiol 49:1767-1782. https://doi.org/10. 1093/pcp/pcn 150

Fricke J, Blei F, Hoffmeister D (2017) Enzymatic Synthesis of Psilocybin. Angew Chemie Int Ed 56:12352-12355. https://doi.org/ 10.1002/anie.201705489

Gai Q-Y, Jiao J, Wang X, Zang Y-P, Niu L-L, Fu Y-J (2019) Elicitation of Isatis tinctoria L. hairy root cultures by salicylic acid and methyl jasmonate for the enhanced production of pharmacologically active alkaloids and flavonoids. Plant Cell Tissue Organ Cult 137:77-86. https://doi.org/10.1007/ s11240-018-01553-8

Gharari Z, Bagheri K, Danafar H, Sharafi A (2020a) Enhanced flavonoid production in hairy root cultures of Scutellaria bornmuelleri by elicitor induced over-expression of MYB7 and FNSח2 genes. Plant Physiol Biochem 148:35-44. https://doi.org/10. 1016/j.plaphy.2020.01.002

Gharari Z, Bagheri K, Danafar H, Sharafi A (2020b) Simultaneous determination of baicalein, chrysin and wogonin in four Iranian Scutellaria species by high performance liquid chromatography. J Appl Res Med Aromat Plants 16:100232. https://doi.org/10. 1016/j.jarmap.2019.100232

Ghisalberti EL (2000) Lantana camara L. (Verbenaceae). Fitoterapia 71:467-486. https://doi.org/10.1016/S0367-326X(00)00202-1

Gikas E, Alesta A, Economou G, Karamanos A, Tsarbopoulos A (2008) Determination of Isoflavones in the Aerial Part of Red Clover by HPLC-Diode Array Detection. J Liq Chromatogr Relat Technol 31:1181-1194. https://doi.org/10.1080/10826 070802000723

Gutierrez-Valdes N, Häkkinen ST, Lemasson C, Guillet M, OksmanCaldentey K-M, Ritala A, Cardon F (2020) Hairy Root Cultures-A Versatile Tool With Multiple Applications. Front Plant Sci 11:33. https://doi.org/10.3389/fpls.2020.00033

Haida Z, Syahida A, Ariff SM, Maziah M, Hakiman M (2019) Factors Affecting Cell Biomass and Flavonoid Production of Ficus deltoidea var. kunstleri in Cell Suspension Culture System. Sci Rep 9:9533. https://doi.org/10.1038/s41598-019-46042-w

Hamburger M (2002) Isatis tinctoria - From the rediscovery of an ancient medicinal plant towards a novel anti-inflammatory phytopharmaceutical. Phytochem Rev 1:333-344. https://doi.org/10. 1023/A:1026095608691
Hibino K, Ushiyama K (1999) Commercial Production of Ginseng by Plant Tissue Culture Technology. In: Fu T-J, Singh G, Curtis WR (eds) Plant Cell and Tissue Culture for the Production of Food Ingredients. Springer, US, Boston, MA, pp 215-224

Hippolyte I, Marin B, Baccou JC, Jonard R (1992) Growth and rosmarinic acid production in cell suspension cultures of Salvia officinalis L. Plant Cell Rep 11:109-112. https://doi.org/10.1007/ BF00232160

Hoefgen S, Lin J, Fricke J, Stroe MC, Mattern DJ, Kufs JE, Hortschansky P, Brakhage AA, Hoffmeister D, Valiante V (2018) Facile assembly and fluorescence-based screening method for heterologous expression of biosynthetic pathways in fungi. Metab Eng 48:44-51. https://doi.org/10.1016/j.ymben.2018.05.014

Ikram NKBK, Simonsen HT (2017) A Review of Biotechnological Artemisinin Production in Plants. Front Plant Sci 8:1966. https:// doi.org/10.3389/fpls.2017.01966

Imanshahidi M, Hosseinzadeh H (2008) Pharmacological and therapeutic effects of Berberis vulgaris and its active constituent, berberine. Phyther Res 22:999-1012. https://doi.org/10.1002/ ptr.2399

Ionkova I (2007) Biotechnological Approaches for the Production of Lignans. Pharmacogn Rev 1:57-68

Jalalipour Parizi K, Rahpeyma SA, Pourseyedi S (2020) The novel paclitaxel-producing system: establishment of Corylus avellana L. hairy root culture. Vitr Cell Dev Biol - Plant 56:290-297. https://doi.org/10.1007/s11627-019-10050-2

Jiang D, Liu Y, Tang Z, Wang M, Kong X, Lyu Y, Song Z, Zhao P (2018) Optimization on Extraction Technology and Determination of Mulberroside A in Morus alba (L.) by UPLC. Nat. Prod. Res. Dev. 30:1971-1977. https://doi.org/10.16333/j.1001-6880. 2018.11.020

Jiang X-L, Piao X-C, Gao R, Jin M-Y, Jiang J, Jin X-H, Lian M-L (2017) Improvement of bioactive compound accumulation in adventitious root cultures of an endangered plant species, Oplopanaxelatus. Acta Physiol Plant 39:226. https://doi.org/10.1007/ s11738-017-2525-3

Kabita KC, Sanatombi K, Sharma SK (2020) Efficient enhancement of capsaicinoids biosynthesis in cell suspension cultures of Capsicum chinense Jacq. cv. 'Umorok' by elicitors and differential gene expression analysis of elicited cultures. Plant Cell Tissue Organ Cult 141:145-154. https://doi.org/10.1007/ s11240-020-01775-9

Kacprzak KM (2013) Chemistry and Biology of Camptothecin and its Derivatives. In: Ramawat KG, Mérillon J-M (eds) Natural Products: Phytochemistry, Botany and Metabolism of Alkaloids, Phenolics and Terpenes. Springer Berlin Heidelberg, Berlin, pp 643-682

Kai G, Wu C, Gen L, Zhang L, Cui L, Ni X (2015) Biosynthesis and biotechnological production of anti-cancer drug Camptothecin. Phytochem Rev 14:525-539. https://doi.org/10.1007/ s11101-015-9405-5

Kallam K, Appelhagen I, Luo J, Albert N, Zhang H, Deroles S, Hill L, Findlay K, Andersen ØM, Davies K, Martin C (2017) Aromatic Decoration Determines the Formation of Anthocyanic Vacuolar Inclusions. Curr Biol 27:945-957. https://doi.org/10.1016/j.cub. 2017.02.027

Kallscheuer N, Vogt M, Bott M, Marienhagen J (2017) Functional expression of plant-derived $\mathrm{O}$-methyltransferase, flavanone 3-hydroxylase, and flavonol synthase in Corynebacterium glutamicum for production of pterostilbene, kaempferol, and quercetin. J Biotechnol 258:190-196. https://doi.org/10.1016/j.jbiotec. 2017.01.006

Kallscheuer N, Vogt M, Stenzel A, Gätgens J, Bott M, Marienhagen J (2016) Construction of a Corynebacterium glutamicum platform strain for the production of stilbenes and (2S)-flavanones. Metab Eng 38:47-55. https://doi.org/10.1016/j.ymben.2016.06.003 
Karuppusamy S (2009) A review on trends in production of secondary metabolites from higher plants by in vitro tissue, organ and cell cultures. J Med Plants Res 3:1222-1239. https://doi.org/10.5897/ JMPR.9000026

Kehie M, Kumaria S, Tandon P, Ramchiary N (2015) Biotechnological advances on in vitro capsaicinoids biosynthesis in capsicum: a review. Phytochem Rev 14:189-201. https://doi.org/10.1007/ s11101-014-9344-6

Kinghorn AD, Pan L, Fletcher JN, Chai H (2011) The relevance of higher plants in lead compound discovery programs. J Nat Prod 74:1539-1555. https://doi.org/10.1021/np200391c

Kingston DGI (2011) Modern Natural Products Drug Discovery and Its Relevance to Biodiversity Conservation. J Nat Prod 74:496-511. https://doi.org/10.1021/np100550t

Klockgether-Radke AP (2002) F. W. Sertürner und die Entdeckung des Morphins. 200 Jahre Schmerztherapie mit Opioiden. Anasthesiol Intensivmed Notfallmedizin Schmerztherapie 37:244-249. https://doi.org/10.1055/s-2002-30132

Kohnen-Johannsen LK, Kayser O (2019) Tropane Alkaloids: chemistry, pharmacology, biosynthesis and production. Molecules 24:796. https://doi.org/10.3390/molecules24040796

Komaikul J, Kitisripanya T, Inyai C, Likhitwitayawuid K, Sritularak B, Tanaka H, Putalun W (2019) Phytostilbenoid production in white mulberry (Morus alba L.) cell culture using bioreactors and simple deglycosylation by endogenous enzymatic hydrolysis. Vitr Cell Dev Biol - Plant 55:199-208. https://doi.org/10.1007/ s11627-018-09953-3

Kreis W (2019) Exploiting plant cell culture for natural product formation. J Appl Bot Food Qual 92:216-225. https://doi.org/10.5073/ JABFQ.2019.092.030

Kreis W (2007) In-Vitro Culturing Techniques of Medicinal Plants. In: Kayser O, Quax WJ (eds) Medicinal Plant Biotechnology. From Basic Research to Industrial Applications. Wiley-VCH, Weinheim, pp 159-185

Kuhlmann S, Kranz K, Lücking B, Alfermann AW, Petersen M (2002) Aspects of cytotoxic lignan biosynthesis in suspension cultures of Linum nodiflorum. Phytochem Rev 1:37-43. https://doi.org/ 10.1023/A:1015876001812

Kumar A (2015) Improving Secondary Metabolite Production in Tissue Cultures. In: Bahadur B, Venkat Rajam M, Sahijram L, Krishnamurthy K V (eds) Plant Biology and Biotechnology: Volume II: Plant Genomics and Biotechnology. Springer India, New Delhi, pp 397-406

Kumar P, Chaturvedi R, Sundar D, Bisaria VS (2016) Piriformospora indica enhances the production of pentacyclic triterpenoids in Lantana camara $\mathrm{L}$. suspension cultures. Plant Cell Tissue Organ Cult 125:23-29. https://doi.org/10.1007/s11240-015-0924-y

Kümmritz S, Haas C, Pavlov AI, Geib D, Ulber R, Bley T, Steingroewer J (2014) Determination of Triterpenic Acids and Screening for Valuable Secondary Metabolites in Salvia sp. Suspension Cultures. Nat Prod Commun 9:1934578X1400900107. https:// doi.org/10.1177/1934578X1400900107

Kümmritz S, Louis M, Haas C, Oehmichen F, Gantz S, Delenk H, Steudler S, Bley T, Steingroewer J (2016) Fungal elicitors combined with a sucrose feed significantly enhance triterpene production of a Salvia fruticosa cell suspension. Appl Microbiol Biotechnol 100:7071-7082. https://doi.org/10.1007/ s00253-016-7432-9

Kung SH, Lund S, Murarka A, McPhee D, Paddon CJ (2018) Approaches and Recent Developments for the Commercial Production of Semi-synthetic Artemisinin. Front Plant Sci 9:87. https://doi.org/10.3389/fpls.2018.00087

Lalaleo L, Alcazar R, Palazon J, Moyano E, Cusido RM, Bonfill M (2018) Comparing aryltetralin lignan accumulation patterns in four biotechnological systems of Linum album. J Plant Physiol 228:197-207. https://doi.org/10.1016/j.jplph.2018.06.006

Lange BM (2018) Commercial-Scale Tissue Culture for the Production of Plant Natural Products: Successes, Failures and Outlook. In: Schwab W, Lange BM, Wüst M (eds) Biotechnology of Natural Products. Springer International Publishing, Cham, pp 189-218

Le K-C, Jeong C-S, Lee H, Paek K-Y, Park S-Y (2019) Ginsenoside accumulation profiles in long- and short-term cell suspension and adventitious root cultures in Panax ginseng. Hortic Environ Biotechnol 60:125-134. https://doi.org/10.1007/s13580-018-0108-x

Lee J-Y, Hiyama M, Hikosaka S, Goto E (2020) Effects of Concentration and Temperature of Nutrient Solution on Growth and Camptothecin Accumulation of Ophiorrhiza pumila. Plants 9:793. https://doi.org/10.3390/plants9060793

Li JWH, Vederas JC (2009) Drug discovery and natural products: End of era or an endless frontier? Science 325:161-165. https://doi. org/10.1126/science.1168243

Li S, Wang D, Liu Y, Lin T, Tang J, Hua E, Zhang X, Dai Z, Huang L (2017) Research on the heterologous high-efficiency synthesis of cucurbitadienol. China J Chinese Mater Medica 42:3326-3331

Li Y, Li S, Thodey K, Trenchard I, Cravens A, Smolke CD (2018) Complete biosynthesis of noscapine and halogenated alkaloids in yeast. Proc Natl Acad Sci 115:E3922 LP-E3931. https://doi. org/10.1073/pnas.1721469115

Li Z, Wang X, Zhang H (2019) Balancing the non-linear rosmarinic acid biosynthetic pathway by modular co-culture engineering. Metab Eng 54:1-11. https://doi.org/10.1016/j.ymben.2019.03. 002

Lichius JJ, Willuhn G, Loew D (2016) Calendulae flos. In: Blaschek W (ed) Wichtl - Teedrogen und Phytopharmaka, 6th edn. Wissenschaftliche Verlagsgesellschaft, Stuttgart, pp 136-139

Liu Y-Q, Li W-Q, Morris-Natschke SL, Qian K, Yang L, Zhu G-X, Wu X-B, Chen A-L, Zhang S-Y, Nan X, Lee K-H (2015) Perspectives on Biologically Active Camptothecin Derivatives. Med Res Rev 35:753-789. https://doi.org/10.1002/med.21342

Liu Z-B, Chen J-G, Yin Z-P, Shangguan X-C, Peng D-Y, Lu T, Lin P (2018) Methyl jasmonate and salicylic acid elicitation increase content and yield of chlorogenic acid and its derivatives in Gardenia jasminoides cell suspension cultures. Plant Cell Tissue Organ Cult 134:79-93. https://doi.org/10.1007/ s11240-018-1401-1

Lu D, Dong J, Jin H, Sun L, Xu X, Zhou T, Zhu Y, Xu M (2011) Nitrate reductase-mediated nitric oxide generation is essential for fungal elicitor-induced camptothecin accumulation of Camptotheca acuminata suspension cell cultures. Appl Microbiol Biotechnol 90:1073-1081. https://doi.org/10.1007/s00253-011-3146-1

Luo X, Reiter MA, D’Espaux L, Wong J, Denby CM, Lechner A, Zhang Y, Grzybowski AT, Harth S, Lin W, Lee H, Yu C, Shin J, Deng K, Benites VT, Wang G, Baidoo EEK, Chen Y, Dev I, Petzold CJ, Keasling JD (2019) Complete biosynthesis of cannabinoids and their unnatural analogues in yeast. Nature 567:123-126. https://doi.org/10.1038/s41586-019-0978-9

Majdi C, Pereira C, Dias MI, Calhelha RC, Alves MJ, Rhourri-Frih B, Charrouf Z, Barros L, Amaral JS, Ferreira ICFR (2020) Phytochemical Characterization and Bioactive Properties of Cinnamon Basil (Ocimum basilicum cv. 'Cinnamon') and Lemon Basil (Ocimum $\times$ citriodorum). Antioxidants 9:369. https://doi.org/10. 3390/antiox 9050369

Makri O, Kintzios S (2008) Ocimum sp. (Basil): Botany, Cultivation, Pharmaceutical Properties, and Biotechnology. J Herbs Spices Med Plants 13:123-150. https://doi.org/10.1300/J044v13n03_10

Marchev AS, Yordanova ZP, Georgiev MI (2020) Green (cell) factories for advanced production of plant secondary metabolites. Crit Rev Biotechnol 40:443-458. https://doi.org/10.1080/07388 551.2020 .1731414 
Marsafari M, Xu P (2020) Debottlenecking mevalonate pathway for antimalarial drug precursor amorphadiene biosynthesis in Yarrowia lipolytica. Metab Eng Commun 10:e00121. https://doi.org/ 10.1016/j.mec.2019.e00121

McChesney JD, Venkataraman SK, Henri JT (2007) Plant natural products: Back to the future or into extinction? Phytochemistry 68:2015-2022. https://doi.org/10.1016/J.PHYTOCHEM.2007. 04.032

McElroy C, Jennewein S (2018) Taxol® Biosynthesis and Production: From Forests to Fermenters. In: Schwab W, Lange BM, Wüst M (eds) Biotechnology of Natural Products. Springer International Publishing, Cham, pp 145-185

Milne N, Thomsen P, Mølgaard Knudsen N, Rubaszka P, Kristensen M, Borodina I (2020) Metabolic engineering of Saccharomyces cerevisiae for the de novo production of psilocybin and related tryptamine derivatives. Metab Eng 60:25-36. https://doi.org/10. 1016/j.ymben.2019.12.007

Min K, Park K, Park D-H, Yoo YJ (2015) Overview on the biotechnological production of L-DOPA. Appl Microbiol Biotechnol 99:575-584. https://doi.org/10.1007/s00253-014-6215-4

Mirjalili M, Moyano E, Bonfill M, Cusido R, Palazón J (2009) Steroidal Lactones from Withania somnifera, an Ancient Plant for Novel Medicine. Molecules 14:2373-2393. https://doi.org/10. 3390/molecules 14072373

Modarres M, Esmaeilzadeh Bahabadi S, Taghavizadeh Yazdi ME (2018) Enhanced production of phenolic acids in cell suspension culture of Salvia leriifolia Benth. using growth regulators and sucrose. Cytotechnology 70:741-750. https://doi.org/10. 1007/s10616-017-0178-0

Monforte-González M, Serrano-Gamboa JG, Guízar-González C, Miranda-Ham ML, Vázquez-Flota FA (2019) Alkaloid synthesis is coupled to shoot morphogenesis in Argemone mexicana L. (Papaveraceae) in vitro cultures. Vitr Cell Dev Biol - Plant 55:695-701. https://doi.org/10.1007/s11627-019-10007-5

Moses T, Mehrshahi P, Smith AG, Goossens A (2017) Synthetic biology approaches for the production of plant metabolites in unicellular organisms. J Exp Bot 68:4057-4074. https://doi. org/10.1093/jxb/erx 119

Murthy HN, Dandin VS, Park S-Y, Paek K-Y (2018) Quality, safety and efficacy profiling of ginseng adventitious roots produced in vitro. Appl Microbiol Biotechnol 102:7309-7317. https:// doi.org/10.1007/s00253-018-9188-x

Murthy HN, Georgiev MI, Kim Y-S, Jeong C-S, Kim S-J, Park S-Y, Paek K-Y (2014) Ginsenosides: prospective for sustainable biotechnological production. Appl Microbiol Biotechnol 98:6243-6254. https://doi.org/10.1007/s00253-014-5801-9

Mustafa NR, de Winter W, van Iren F, Verpoorte R (2011) Initiation, growth and cryopreservation of plant cell suspension cultures. Nat Protoc 6:715-742. https://doi.org/10.1038/nprot.2010.144

Neag MA, Mocan A, Echeverría J, Pop RM, Bocsan CI, Crişan G, Buzoianu AD (2018) Berberine: Botanical Occurrence, Traditional Uses, Extraction Methods, and Relevance in Cardiovascular, Metabolic, Hepatic, and Renal Disorders. Front Pharmacol 9:557. https://doi.org/10.3389/fphar.2018.00557

Oberhofer M, Wackerlig J, Zehl M, Büyük H, Cao JJ, Prado-Roller A, Urban E, Zotchev SB (2021) Endophytic Akanthomyces sp. LN303 from Edelweiss Produces Emestrin and Two New 2-Hydroxy-4 Pyridone Alkaloids. ACS Omega 6:2184-2191. https://doi.org/10.1021/acsomega.0c05472

Ochoa-Villarreal M, Howat S, Hong S, Jang MO, Jin Y-W, Lee E-K, Loake GJ (2016) Plant cell culture strategies for the production of natural products. BMB Rep 49:149-158. https://doi.org/10. 5483/bmbrep.2016.49.3.264

Panche AN, Diwan AD, Chandra SR (2016) Flavonoids: an overview. J Nutr Sci 5:e47. https://doi.org/10.1017/jns.2016.41
Patel DK, Kumar R, Sairam K, Hemalatha S (2013) Hybanthus enneaspermus (L.) F. Muell: a concise report on its phytopharmacological aspects. Chin J Nat Med 11:199-206. https:// doi.org/10.1016/S1875-5364(13)60017-5

Patra N, Srivastava AK (2016) Artemisinin production by plant hairy root cultures in gas- and liquid-phase bioreactors. Plant Cell Rep 35:143-153. https://doi.org/10.1007/s00299-015-1875-9

Peplow M (2016) Synthetic malaria drug meets market resistance. Nature 530:389-390. https://doi.org/10.1038/530390a

Pezeshki S, Petersen M (2018) Rosmarinic Acid and Related Metabolites. In: Schwab W, Lange BM, Wüst M (eds) Biotechnology of Natural Products. Springer International Publishing, Cham, pp 25-60

Pferschy-Wenzig EM, Bauer R (2015) The relevance of pharmacognosy in pharmacological research on herbal medicinal products. Epilepsy Behav 52:344-362. https://doi.org/10.1016/j. yebeh.2015.05.037

Preil W (2003) Micropropagation of ornamental plants. In: Laimer M, Rücker W (eds) Plant Tissue Culture: 100 years since Gottlieb Haberlandt. Springer Vienna, Vienna, pp 115-133

Qiao J, Luo Z, Cui S, Zhao H, Tang Q, Mo C, Ma X, Ding Z (2019) Modification of isoprene synthesis to enable production of cucurbitadienol synthesis in Saccharomyces cerevisiae. J Ind Microbiol Biotechnol 46:147-157. https://doi.org/10.1007/ s10295-018-2116-3

Rahmat E, Kang Y (2019) Adventitious root culture for secondary metabolite production in medicinal plants: A review. J Plant Biotechnol 46:143-157. https://doi.org/10.5010/JPB.2019.46.3.143

Ramirez-Estrada K, Vidal-Limon H, Hidalgo D, Moyano E, Golenioswki M, Cusidó R, Palazon J (2016) Elicitation, an Effective Strategy for the Biotechnological Production of Bioactive HighAdded Value Compounds in Plant Cell Factories. Molecules 21:182. https://doi.org/10.3390/molecules21020182

Rates SM (2001) Plants as source of drugs. Toxicon 39:603-613. https://doi.org/10.1016/S0041-0101(00)00154-9

Reinisalo M, Kårlund A, Koskela A, Kaarniranta K, Karjalainen RO (2015) Polyphenol Stilbenes: Molecular Mechanisms of Defence against Oxidative Stress and Aging-Related Diseases. Oxid Med Cell Longev 2015:340520. https://doi.org/10.1155/2015/340520

Reis A, Scopel M, Zuanazzi JAS (2018) Trifolium pratense: Friable calli, cell culture protocol and isoflavones content in wild plants, in vitro and cell cultures analyzed by UPLC. Rev Bras Farmacogn 28:542-550. https://doi.org/10.1016/j.bjp.2018.06.004

Ressmann AK, Kremsmayr T, Gaertner P, Zirbs R, Bica K (2017) Toward a benign strategy for the manufacturing of betulinic acid. Green Chem 19:1014-1022. https://doi.org/10.1039/C6GC0 2641A

Robinson MM, Zhang X (2011) the World Medicines Situation 2011 Traditional Medicines : Global Situation, Issues and Challenges. World Health Organization, Geneva

Saiman MZ, Miettinen K, Mustafa NR, Choi YH, Verpoorte R, Schulte AE (2018) Metabolic alteration of Catharanthus roseus cell suspension cultures overexpressing geraniol synthase in the plastids or cytosol. Plant Cell Tissue Organ Cult 134:41-53. https://doi. org/10.1007/s11240-018-1398-5

Salehi M, Karimzadeh G, Naghavi MR (2019a) Synergistic effect of coronatine and sorbitol on artemisinin production in cell suspension culture of Artemisia aпnиа L. cv. Anamed Plant Cell Tissue Organ Cult 137:587-597. https://doi.org/10.1007/ s11240-019-01593-8

Salehi M, Moieni A, Safaie N, Farhadi S (2019b) New synergistic co-culture of Corylus avellana cells and Epicoccum nigrum for paclitaxel production. J Ind Microbiol Biotechnol 46:613-623. https://doi.org/10.1007/s10295-019-02148-8

Salim AA, Chin Y-W, Kinghorn AD (2008) Drug Discovery from Plants. In: Ramawat KG, Merillon JM (eds) Bioactive Molecules 
and Medicinal Plants. Springer Berlin Heidelberg, Berlin, pp $1-24$

Saloniemi H, Wähälä K, Nykänen-Kurki P, Kallela K, Saastamoinen I (1995) Phytoestrogen Content and Estrogenic Effect of Legume Fodder. Proc Soc Exp Biol Med 208:13-17. https://doi.org/10. 3181/00379727-208-43825

Sathish S, Vasudevan V, Karthik S, Elayaraja D, Pavan G, Ajithan C, Manickavasagam M (2020) Elicitors induced L-Dopa accumulation in adventitious root cultures of Hybanthus enneaspermus (L.) F. Muell Vegetos 33:304-312. https://doi.org/10.1007/ s42535-020-00108-7

Sato F, Yamada Y (1984) High berberine-producing cultures of Coptis japonica cells. Phytochemistry 23:281-285. https://doi.org/10. 1016/S0031-9422(00)80318-0

Schmidt TJ, Hemmati S, Klaes M, Konuklugil B, Mohagheghzadeh A, Ionkova I, Fuss E, Wilhelm Alfermann A (2010) Lignans in flowering aerial parts of Linum species - Chemodiversity in the light of systematics and phylogeny. Phytochemistry 71:17141728. https://doi.org/10.1016/j.phytochem.2010.06.015

Shafi N, Ikram M (1982) Quantitative Survey of Rutin-containing Plants Part 1. Int J Crude Drug Res 20:183-186. https://doi. org/10.3109/13880208209083302

Shang X, He X, He X, Li M, Zhang R, Fan P, Zhang Q, Jia Z (2010) The genus Scutellaria an ethnopharmacological and phytochemical review. J Ethnopharmacol 128:279-313. https://doi. org/10.1016/j.jep.2010.01.006

Sharma A, Amin D, Sankaranarayanan A, Arora R, Mathur AK (2020) Present status of Catharanthus roseus monoterpenoid indole alkaloids engineering in homo- and hetero-logous systems. Biotechnol Lett 42:11-23. https://doi.org/10.1007/ s10529-019-02757-4

Sharma A, Verma P, Mathur A, Mathur AK (2018) Genetic engineering approach using early Vinca alkaloid biosynthesis genes led to increased tryptamine and terpenoid indole alkaloids biosynthesis in differentiating cultures of Catharanthus roseus. Protoplasma 255:425-435. https://doi.org/10.1007/ s00709-017-1151-7

Shi M, Gong H, Cui L, Wang Q, Wang C, Wang Y, Kai G (2020) Targeted metabolic engineering of committed steps improves anti-cancer drug camptothecin production in Ophiorrhiza pumila hairy roots. Ind Crops Prod 148:112277. https://doi.org/ 10.1016/j.indcrop.2020.112277

Shikov AN, Pozharitskaya ON, Makarov VG, YANG W-Z, GUO D-A, (2014) Oplopanax elatus (Nakai) Nakai: chemistry, traditional use and pharmacology. Chin J Nat Med 12:721-729. https://doi. org/10.1016/S1875-5364(14)60111-4

Singh P, Prasad R, Tewari R, Jaidi M, Kumar S, Rout PK, Rahman L, ur, (2018) Silencing of quinolinic acid phosphoribosyl transferase (QPT) gene for enhanced production of scopolamine in hairy root culture of Duboisia leichhardtii. Sci Rep 8:13939. https://doi.org/10.1038/s41598-018-32396-0

Sivanandhan G, Selvaraj N, Ganapathi A, Manickavasagam M (2014) Enhanced Biosynthesis of Withanolides by Elicitation and Precursor Feeding in Cell Suspension Culture of Withania somnifera (L.) Dunal in Shake-Flask Culture and Bioreactor. PLoS One 9:e104005. https://doi.org/10.1371/journal.pone.0104005

Smollny T, Wichers H, Kalenberg S, Shahsavari A, Petersen M, Alfermann AW (1998) Accumulation of podophyllotoxin and related lignans in cell suspension cultures of Linum album. Phytochemistry 48:975-979. https://doi.org/10.1016/S0031-9422(97)00957-6

Srivastava S, Cahill DM, Conlan XA, Adholeya A (2014) A Novel in Vitro Whole Plant System for Analysis of Polyphenolics and Their Antioxidant Potential in Cultivars of Ocimum basilicum. J Agric Food Chem 62:10064-10075. https://doi.org/10.1021/ jf502709e
Staniek A, Bouwmeester H, Fraser PD, Kayser O, Martens S, Tissier A, van der Krol S, Wessjohann L, Warzecha1 H (2014) Natural products - learning chemistry from plants. Biotechnol J 9:326336. https://doi.org/10.1002/biot.201300059

Sticher O (2007a) Phenolische Verbindungen. In: Hänsel R, Sticher O (eds) Pharmakognosie - Phytopharmazie, 8th edn. Springer, Heidelberg, pp 1141-1241

Sticher O (2007b) Isoprenoide als Inhaltsstoffe. In: Hänsel R, Sticher O (eds) Pharmakognosie - Phytopharmazie, 8th edn. Springer, Heidelberg, pp 809-914

Sukito A, Tachibana S (2016) Effect of methyl jasmonate and salycilic acid synergism on enhancement of bilobalide and ginkgolide production by immobilized cell cultures of Ginkgo biloba. Bioresour Bioprocess 3:24. https://doi.org/10.1186/s40643-016-0101-0

Sun J, Peebles CAM (2016) Engineering overexpression of ORCA3 and strictosidine glucosidase in Catharanthus roseus hairy roots increases alkaloid production. Protoplasma 253:1255-1264. https://doi.org/10.1007/s00709-015-0881-7

Sykłowska-Baranek K, Rymaszewski W, Gaweł M, Rokicki P, Pilarek M, Grech-Baran M, Hennig J, Pietrosiuk A (2019) Comparison of elicitor-based effects on metabolic responses of Taxus $\times$ media hairy roots in perfluorodecalin-supported two-phase culture system. Plant Cell Rep 38:85-99. https://doi.org/10.1007/ s00299-018-2351-0

Talano MA, Oller ALW, Agostini PSG, E (2012) Hairy Roots, their Multiple Applications and Recent Patents. Recent Pat Biotechnol. 6:115-133. https://doi.org/10.2174/187220812801784713

Tam DNH, Truong DH, Nguyen TTH, Quynh LN, Tran L, Nguyen HD, Shamandy B eldin, Le TMH, Tran DK, Sayed D, Vu VV, Mizukami S, Hirayama K, Huy NT (2018) Ginsenoside Rh1: A Systematic Review of Its Pharmacological Properties. Planta Med 84:139-152. https://doi.org/10.1055/s-0043-124087

Tetali SD (2019) Terpenes and isoprenoids: a wealth of compounds for global use. Planta 249:1-8. https://doi.org/10.1007/ s00425-018-3056- $\mathrm{x}$

Trantas EA, Koffas MAG, Xu P, Ververidis F (2015) When plants produce not enough or at all: metabolic engineering of flavonoids in microbial hosts. Front Plant Sci 6:7. https://doi.org/10.3389/ fpls.2015.00007

Ulbrich B, Wiesner W, Arens H (1985) Large-Scale Production of Rosmarinic Acid from Plant Cell Cultures of Coleus blumei Benth. In: Neumann K-H, Barz W, Reinhard E (eds) Primary and Secondary Metabolism of Plant Cell Cultures. Springer Berlin Heidelberg, Berlin, pp 293-303

Upadhyay R, Rao LJM (2013) An Outlook on Chlorogenic AcidsOccurrence, Chemistry, Technology, and Biological Activities. Crit Rev Food Sci Nutr 53:968-984. https://doi.org/10.1080/ 10408398.2011.576319

Urban MC (2015) Accelerating extinction risk from climate change. Science 348:571-573. https://doi.org/10.1126/science.aaa4984

Verpoorte R, Contin A, Memelink J (2002) Biotechnology for the production of plant secondary metabolites. Phytochem Rev 1:13-25. https://doi.org/10.1023/A:1015871916833

Volk R-B, Wichtl M, Loew D (2016) Ginkgo folium. In: Blaschek W (ed) Wichtl - Teedrogen und Phytopharmaka, 6th edn. Wissenschaftliche Verlagsgesellschaft, Stuttgart, pp 290-293

Wang D, Wang J, Shi Y, Li R, Fan F, Huang Y, Li W, Chen N, Huang L, Dai Z, Zhang X (2020) Elucidation of the complete biosynthetic pathway of the main triterpene glycosylation products of Panax notoginseng using a synthetic biology platform. Metab Eng 61:131-140. https://doi.org/10.1016/j.ymben.2020.05.007

Wang X, Huang Y, Mort AJ, Zeng Y, Tauer CG, Cochran KD (2006) Variation of Taxane Content in Needles of Taxus x media Cultivars with Different Growth Characteristics. Zeitschrift Für Naturforsch C 61:619-624. https://doi.org/10.1515/znc-2006-9-1001 
Wang Y, Yang B, Zhang M, Jia S, Yu F (2019) Application of transport engineering to promote catharanthine production in Catharanthus roseus hairy roots. Plant Cell Tissue Organ Cult 139:523530. https://doi.org/10.1007/s11240-019-01696-2

Wang Z-Y, Zhong J-J (2002) Repeated elicitation enhances taxane production in suspension cultures of Taxus chinensis in bioreactors. Biotechnol Lett 24:445-448. https://doi.org/10.1023/A:10145 49008516

Wani KI, Choudhary S, Zehra A, Naeem M, Weathers P, Aftab T (2021) Enhancing artemisinin content in and delivery from Artemisia annua: a review of alternative, classical, and transgenic approaches. Planta 254:29. https://doi.org/10.1007/ s00425-021-03676-3

Wawrosch C, Schwaiger S, Stuppner H, Kopp B (2013) Leoligin formation in transformed hairy roots of Edelweiss (Leontopodium alpinum Cass.). Planta Med 79:1276. https://doi.org/10.1055/s0033-1352459

Wawrosch C, Schwaiger S, Stuppner H, Kopp B (2014) Lignan formation in hairy root cultures of Edelweiss (Leontopodium nivale ssp. alpinum (Cass.) Greuter). Fitoterapia 97:219-223. https:// doi.org/10.1016/j.fitote.2014.06.008

Wen P, Hu T-G, Linhardt RJ, Liao S-T, Wu H, Zou Y-X (2019) Mulberry: A review of bioactive compounds and advanced processing technology. Trends Food Sci Technol 83:138-158. https:// doi.org/10.1016/j.tifs.2018.11.017

Wu J, Zhong J-J (1999) Production of ginseng and its bioactive components in plant cell culture: Current technological and applied aspects. J Biotechnol 68:89-99. https://doi.org/10.1016/S01681656(98)00195-3

Xiao Y, Ji Q, Gao S, Tan H, Chen R, Li Q, Chen J, Yang Y, Zhang L, Wang Z, Chen W, Hu Z (2015) Combined transcriptome and metabolite profiling reveals that IiPLR1 plays an important role in lariciresinol accumulation in Isatis indigotica. J Exp Bot 66:6259-6271. https://doi.org/10.1093/jxb/erv333
Yaldiz G, Ozguven M, Sekeroglu N (2010) Variation in capsaicin contents of different Capsicum species and lines by varying drying parameters. Ind Crops Prod 32:434-438. https://doi.org/10. 1016/j.indcrop.2010.06.013

Yun DJ, Hashimoto T, Yamada Y (1992) Metabolic engineering of medicinal plants: transgenic Atropa belladonna with an improved alkaloid composition. Proc Natl Acad Sci 89:11799-11803. https://doi.org/10.1073/pnas.89.24.11799

Zebarjadi A, Dianatkhah S, Mohammadi PP, Qaderi A (2018) Influence of abiotic elicitors on improvement production of artemisinin in cell culture of Artemisia annиa L. Cell Mol Biol 64:1-5. https:// doi.org/10.14715/cmb/2018.64.9.1

Zhang Y-H, Zhong J-J (1997) Hyperproduction of ginseng saponin and polysaccharide by high density cultivation of Panax notoginseng cells. Enzyme Microb Technol 21:59-63. https://doi.org/10. 1016/S0141-0229(96)00224-4

Zhao Y, Fan J, Wang C, Feng X, Li C (2018) Enhancing oleanolic acid production in engineered Saccharomyces cerevisiae. Bioresour Technol 257:339-343. https://doi.org/10.1016/j.biortech.2018. 02.096

Zirpel B, Degenhardt F, Martin C, Kayser O, Stehle F (2017) Engineering yeasts as platform organisms for cannabinoid biosynthesis. $\mathrm{J}$ Biotechnol 259:204-212. https://doi.org/10.1016/j.jbiotec.2017. 07.008

Zirpel B, Stehle F, Kayser O (2015) Production of $\Delta 9$-tetrahydrocannabinolic acid from cannabigerolic acid by whole cells of Pichia (Komagataella) pastoris expressing $\Delta$ 9-tetrahydrocannabinolic acid synthase from Cannabis sativa L. Biotechnol Lett 37:1869-1875. https://doi.org/10.1007/ s10529-015-1853-x

Publisher's note Springer Nature remains neutral with regard to jurisdictional claims in published maps and institutional affiliations. 